Review Article

\title{
Critical Roles of Reactive Oxygen Species in Age-Related Impairment in Ischemia-Induced Neovascularization by Regulating Stem and Progenitor Cell Function
}

\author{
Yuen Ting Lam \\ The Heart Research Institute, 7 Eliza Street, Newtown, Sydney, NSW 2042, Australia \\ Correspondence should be addressed to Yuen Ting Lam; monica.lam@hri.org.au
}

Received 9 April 2015; Accepted 12 August 2015

Academic Editor: Felipe Simon

Copyright (C) 2016 Yuen Ting Lam. This is an open access article distributed under the Creative Commons Attribution License, which permits unrestricted use, distribution, and reproduction in any medium, provided the original work is properly cited.

Reactive oxygen species (ROS) regulate bone marrow microenvironment for stem and progenitor cells functions including selfrenewal, differentiation, and cell senescence. In response to ischemia, ROS also play a critical role in mediating the mobilization of endothelial progenitor cells (EPCs) from the bone marrow to the sites of ischemic injury, which contributes to postnatal neovascularization. Aging is an unavoidable biological deteriorative process with a progressive decline in physiological functions. It is associated with increased oxidative stress and impaired ischemia-induced neovascularization. This review discusses the roles of ROS in regulating stem and progenitor cell function, highlighting the impact of unbalanced ROS levels on EPC dysfunction and the association with age-related impairment in ischemia-induced neovascularization. Furthermore, it discusses strategies that modulate the oxidative levels of stem and progenitor cells to enhance the therapeutic potential for elderly patients with cardiovascular disease.

\section{Introduction}

Reactive oxygen species (ROS), such as superoxide anions $\left(\mathrm{O}_{2}{ }^{--}\right)$and hydrogen peroxide $\left(\mathrm{H}_{2} \mathrm{O}_{2}\right)$, are generated as electrons "leak" and react with oxygen molecule $\left(\mathrm{O}_{2}\right)$ during mitochondrial oxidative phosphorylation. Alternatively, the formation of intracellular ROS can be catalyzed by an enzymatic reaction, where NADPH oxidase (Nox) transfers an electron to $\mathrm{O}_{2}$ and generates $\mathrm{O}_{2}{ }^{--}$. Aging is associated with increased oxidative stress that is characterized by an unbalanced redox homeostasis when the rate of ROS formation exceeds the capacity of endogenous antioxidative system to remove ROS. "Free Radical Theory of Aging" proposes that the production of ROS causes an accumulation of cellular damage, including DNA, proteins, and lipids, leading to a decline in mitochondrial integrity. This, in turn, drives a vicious cycle of ROS formation and exacerbates cellular damage, contributing to cellular senescence and premature aging [1]. This theory is supported by numerous studies using a wide range of model organisms, such as Saccharomyces cerevisiae, Drosophila melanogaster, Caenorhabditis elegans, and rodents, demonstrating a strong correlation between increased levels of ROS and oxidatively damaged molecules as cells aged [2-6]. An abnormal elevation of intracellular ROS also has an implication in pathogenesis of various diseases, such as ataxia telangiectasia and Fanconi anemia [7]. Nevertheless, ROS are important for cell signaling and homeostasis. "Redox window" hypothesizes that while excessive ROS contribute to the pathological conditions, appropriate ROS production from mitochondrial oxidative phosphorylation and NADPH oxidase is required for normal physiological responses [8].

Cardiovascular disease is a major cause of world-wide mortality. Aging alone, without any other clinical manifest conditions, is a risk factor for coronary and peripheral artery diseases [9]. The majority of cardiovascular diseaserelated deaths are elderly individuals aged 75 and older. Following ischemia, vascular system is capable of repair and regeneration. The formation of new blood vessels (postnatal neovascularization) relies on two processes: (i) angiogenesis, the sprouting of mature endothelial cells from the preexisting vessels, and (ii) vasculogenesis, the mobilization of bone 


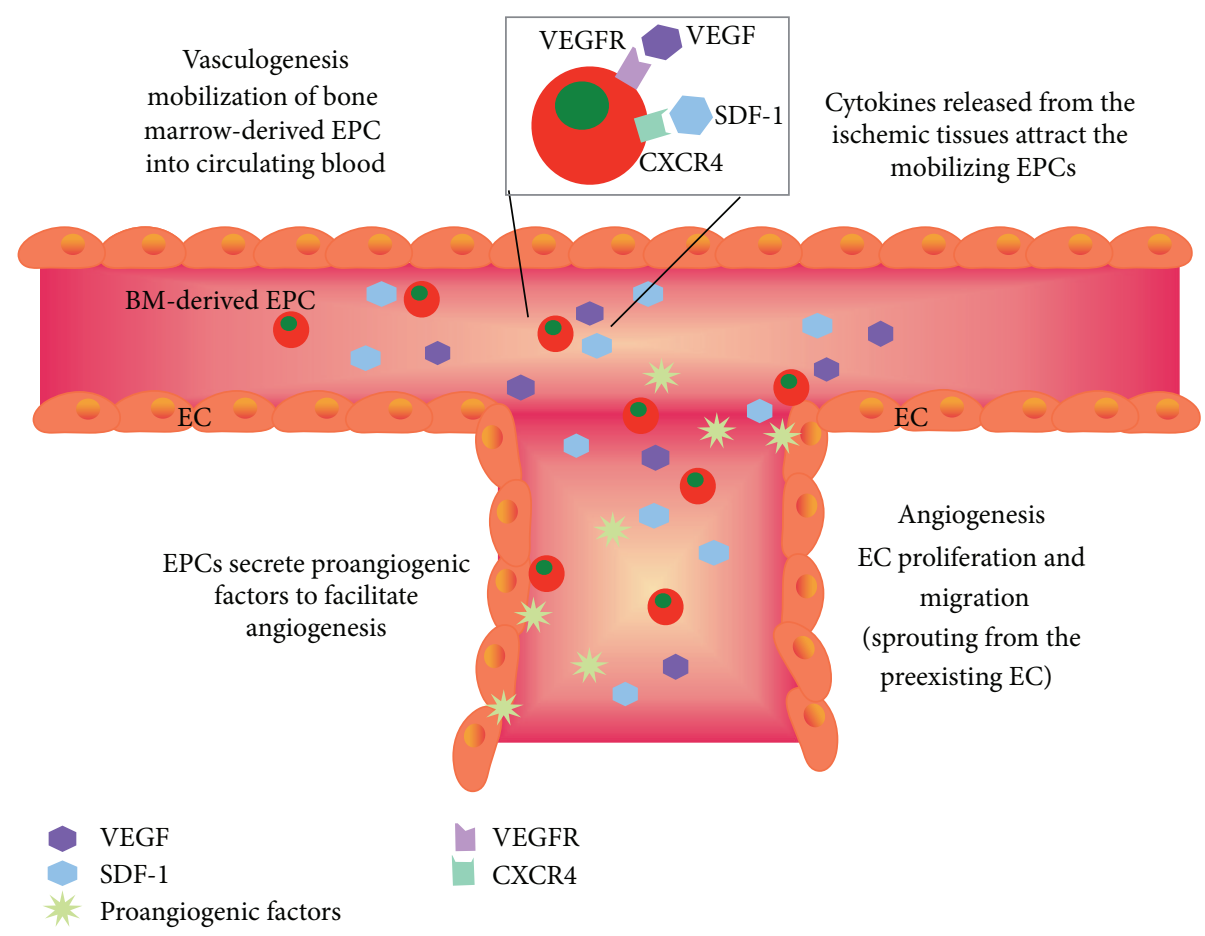

FIGURE 1: Schematic diagram of mechanisms involved in ischemia-induced neovascularization. Ischemia induces angiogenesis, the sprouting of new blood vessels from the preexisting ones. It involves the proliferation and migration of endothelial cells (ECs) at the local ischemic tissues. Cytokines, such as vascular endothelial growth factor (VEGF) and stromal cell-derived factor-1 (SDF-1), are released from the ischemic tissues to facilitate the recruitment of mobilizing endothelial progenitor cells (EPCs) through the binding of receptors. Vasculogenesis involves the proliferation and mobilization of EPCs from bone marrow to the circulating blood. EPCs express various surface receptors, such as VEGF receptor (VEGFR) and C-X-C motif receptor 4 (CXCR4). Once home to the ischemic sites, EPCs are capable of integrating with ECs and promote angiogenesis by secreting proangiogenic factors.

marrow-derived endothelial progenitor cells (EPCs) to the circulation (Figure 1). Aging is associated with impaired ischemia-induced angiogenesis and vasculogenesis in vivo [10-12]. EPCs are a subpopulation of progenitor cells originating from stem cells that differentiate into various lineagecommitted cells. Although studies have used different markers to identify EPCs or referred to different nomenclatures, such as bone marrow-derived angiogenic cells, circulating progenitor cells, or proangiogenic myeloid cells [13-15], it is acknowledged that there is an age-dependent exhaustion of EPC numbers and/or impairment in EPC functions (Table 1).

This review summarizes current understanding of the involvement of (i) redox regulation in self-renewal, differentiation, and senescence of stem and progenitor cells; (ii) ROS as signaling molecules to mobilize progenitor cells from bone marrow to the circulation in response to ischemia; and (iii) how oxidative stress plays a role in age-dependent impairment in ischemia-induced neovascularization. With an increase in global aging population, a major concern is to understand the mechanistic role of age-related impairment in neovascularization in an attempt to develop better cellbased therapeutic strategies for elderly patients with vascular diseases.

\section{The Role of ROS in Maintaining Stem Cell in Bone Marrow Microenvironment}

Stem cells reside in a specialized bone marrow microenvironment (niche) [54]. Hematopoietic stem cells (HSCs) are one of the most characterized adult stem cells, which differentiate into all types of immune cells and maintain blood production. HSCs are predominantly located in hypoxic endosteal niche of the bone marrow with low-oxygen tension where a protection from ROS-related oxidative stress is provided [55, 56]. Jang and Sharkis 2007 have demonstrated that lineage depleted, CD45+ viable cell population ( $\mathrm{Lin}-/ \mathrm{CD} 45+/ \mathrm{AnV}-$ ) could be separated into two fractions based on intracellular ROS levels, indicated by a fluorescence probe $2^{\prime}-7^{\prime}$ dichlorofluorescein diacetate (DCF-DA). The levels of intracellular ROS correlate with stem cell capacities in self-renewal and differentiation. The isolated ROS $^{\text {low }}$ population displays selfrenewal ability by expressing higher levels of telomerase compared to ROS ${ }^{\text {high }}$ population [57]. Telomerase activity has been reported to be associated with the self-renewal potential of HSCs in mice [58]. On the other hand, the expression of a cyclin-dependent kinase inhibitor, p16InK4a, is upregulated in $\operatorname{ROS}^{\text {high }}$ population. As a biomarker of aging, p16Ink4a 
TABLE 1: Examples of age-dependent exhaustion of EPC numbers and reduction of EPC functions.

\begin{tabular}{|c|c|c|c|c|c|}
\hline Study & Subjects & $\begin{array}{l}\text { Source of } \\
\text { cells }\end{array}$ & EPC markers & Effect of aging & Reference \\
\hline $\begin{array}{l}\text { Rauscher et al. } \\
2003\end{array}$ & $\begin{array}{l}\text { 6-month-old versus } \\
\text { 1-month-old ApoE-/- mice }\end{array}$ & $\mathrm{BM}$ & CD31+/CD45- & $\begin{array}{l}\text { Reduced EPC numbers; } \\
\text { progressive development of } \\
\text { atherosclerosis }\end{array}$ & {$[16]$} \\
\hline $\begin{array}{l}\text { Zhang et al. } \\
2006\end{array}$ & $\begin{array}{l}\text { 12-month-old versus } \\
3 \text {-month-old BALB/C mice }\end{array}$ & $\mathrm{BM}$ & CD117+/CD34+/Flk1+ & $\begin{array}{l}\text { Decrease in numbers; reduced } \\
\text { EPC proliferation, migration, } \\
\text { and phagocytic functions }\end{array}$ & [17] \\
\hline $\begin{array}{l}\text { Sugihara et al. } \\
2007\end{array}$ & $\begin{array}{l}\text { 18-month-old versus } \\
\text { 2-month-old } \mathrm{C} 57 \mathrm{Bl} / 6 \mathrm{~J} \text { mice }\end{array}$ & $\mathrm{BM}$ & $\begin{array}{l}\text { AC133+/CD34+ and } \\
\text { CD34+/VEGFR2+ }\end{array}$ & $\begin{array}{l}\text { No difference in numbers of } \\
\text { EPCs; impaired VEGF } \\
\text { production and EPC } \\
\text { migration }\end{array}$ & {$[18]$} \\
\hline $\begin{array}{l}\text { Shimada et al. } \\
2004\end{array}$ & $\begin{array}{l}\text { Klotho mutant }{ }^{*} \text { versus wild } \\
\text { type mice }\end{array}$ & $\begin{array}{l}\text { BM and } \\
\text { peripheral } \\
\text { blood }\end{array}$ & $\begin{array}{l}\text { c-kit+/CD31+ and } \\
\text { CD34+/CD31+ }\end{array}$ & $\begin{array}{l}\text { Decrease in EPC numbers } \\
\text { postischemia }\end{array}$ & [19] \\
\hline \multirow[t]{2}{*}{$\begin{array}{l}\text { Chang et al. } \\
2007\end{array}$} & $\begin{array}{l}\text { 18-24-month-old versus } \\
\text { 4-6-month-old C57Bl/6J }\end{array}$ & $\begin{array}{l}\text { Peripheral } \\
\text { blood and } \\
\text { BM }\end{array}$ & $\begin{array}{l}\text { CD1lb-/Flk1+ and } \\
\text { Scal+/c-kit+/Lin- }\end{array}$ & $\begin{array}{l}\text { Decrease in CD11b-/Flk1+ } \\
\text { numbers in blood, but not } \\
\text { Scal+/c-kit+/Lin- cells in BM } \\
\text { postischemia }\end{array}$ & {$[11]$} \\
\hline & $\begin{array}{l}\text { 68-95-year-old versus } \\
18-35 \text {-year-old human }\end{array}$ & $\begin{array}{l}\text { Peripheral } \\
\text { blood }\end{array}$ & AC133+ & $\begin{array}{l}\text { No difference in EPC numbers } \\
\text { at baseline }\end{array}$ & \\
\hline $\begin{array}{l}\text { Zhuo et al. } \\
2010\end{array}$ & $\begin{array}{l}\text { 15-16-month-old versus } \\
2 \text {-month-old rat }\end{array}$ & $\begin{array}{l}\text { Peripheral } \\
\text { blood and } \\
\text { spleen }\end{array}$ & $\mathrm{CD} 34+/ \mathrm{KDR}+$ & $\begin{array}{l}\text { Decreased numbers in } \\
\text { response to ischemia, but not } \\
\text { at baseline (prior to ischemia) }\end{array}$ & {$[20]$} \\
\hline Shao et al. 2011 & $\begin{array}{l}\text { 24-26-month-old versus } \\
\text { 2-month-old C57Bl/6J mice }\end{array}$ & $\mathrm{BM}$ & $\begin{array}{l}\text { Lin-/Scal+ and } \\
\text { Lin-/Scal+/CXCR4+ }\end{array}$ & $\begin{array}{l}\text { Decrease in } \\
\text { Lin-/Scal+/CXCR4+, but not } \\
\text { Lin-/Scal+ subpopulation }\end{array}$ & {$[21]$} \\
\hline Boon et al. 2011 & $\begin{array}{l}\text { 16-18-month-old versus } \\
\text { 1-month-old C57Bl/6J mice }\end{array}$ & $\begin{array}{l}\text { Peripheral } \\
\text { blood }\end{array}$ & $\begin{array}{l}\text { Lin-/Scal+/c-kit+, } \\
\text { Scal+/c-kit, and } \\
\text { Scal+/Flk1+ }\end{array}$ & Decrease in all 3 populations & {$[22]$} \\
\hline $\begin{array}{l}\text { Scheubel et al. } \\
2003\end{array}$ & $\begin{array}{l}\text { Patients with CAD; } 69 \text { years } \\
\text { old versus younger patients }\end{array}$ & $\begin{array}{l}\text { Peripheral } \\
\text { blood }\end{array}$ & $\mathrm{AC} 133+/ \mathrm{CD} 34+$ & $\begin{array}{l}\text { Reduced basal circulating EPC } \\
\text { levels }\end{array}$ & {$[23]$} \\
\hline $\begin{array}{l}\text { Heiss et al. } \\
2005\end{array}$ & $\begin{array}{l}\text { Healthy elderly (average } 61 \\
\text { years old) versus healthy } \\
\text { young subjects (average } 25 \\
\text { years old) }\end{array}$ & $\begin{array}{l}\text { Peripheral } \\
\text { blood }\end{array}$ & $\begin{array}{l}\mathrm{CD} 133+/ \mathrm{KDR}+\text { and } \\
\mathrm{CD} 34+/ \mathrm{KDR}+\end{array}$ & Comparable levels of EPCs & {$[24]$} \\
\hline
\end{tabular}

expression is found increased in most of rodent tissues with advancing age [59]. The accumulation of pl6Ink4a levels is also associated with decreased repopulating activity and selfrenewal abilities of HSCs in the older mice [60]. Furthermore, ROS $^{\text {high }}$ population exhibits an increase in p38/mitogenactivated protein kinase (MAPK) activation. Elevation of ROS induces phosphorylation of p38/MAPK, which has been reported to limit self-renewal function in HSCs [61]. The reduction of self-renewal ability in ROS $^{\text {high }}$ population can be restored by suppressing ROS production or ROS-induced p38/MAPK activation with antioxidant N-acetyl-L-cysteine (NAC) or p38 specific inhibitor [57].

While low-oxygen niche that limits ROS production is required to maintain HSCs at quiescent state in the bone marrow, the more oxygenic vascular niche (due to the proximity to the blood circulation) is essential for the proliferation and differentiation of stem cells to become progenitor cells (Figure 2). Increased intracellular ROS levels are found during the early stages of embryonic stem cell differentiation. Low levels of $\mathrm{H}_{2} \mathrm{O}_{2}$ induce cardiomyogenesis of embryonic stem (ES) cell, stimulating the proliferation of ES cell-derived cardiomyocytes. Several antioxidative genes and stress resistance genes are downregulated during embryonic stem cell differentiation into embryoid bodies [62]. NADPH oxidase isoforms, Nox1, Nox2, and Nox4, are upregulated; as a result, there is a feed-forward regulation of ROS generation during ES differentiation. Inhibition of Noxderived ROS abolishes ES cardiomyogenesis [63].

\section{Ischemia-Induced ROS Mediate Stem/Progenitor Cell Proliferation and Mobilization}

During early stages of hypoxia, there is a transient elevation of intracellular ROS formation, as detected in various isolated tissues, such as skeletal muscle [64], systemic vessels [65], and myocardium [66]. Hypoxia-induced ROS may be a part of normal physiological response to the imbalance in oxygen 


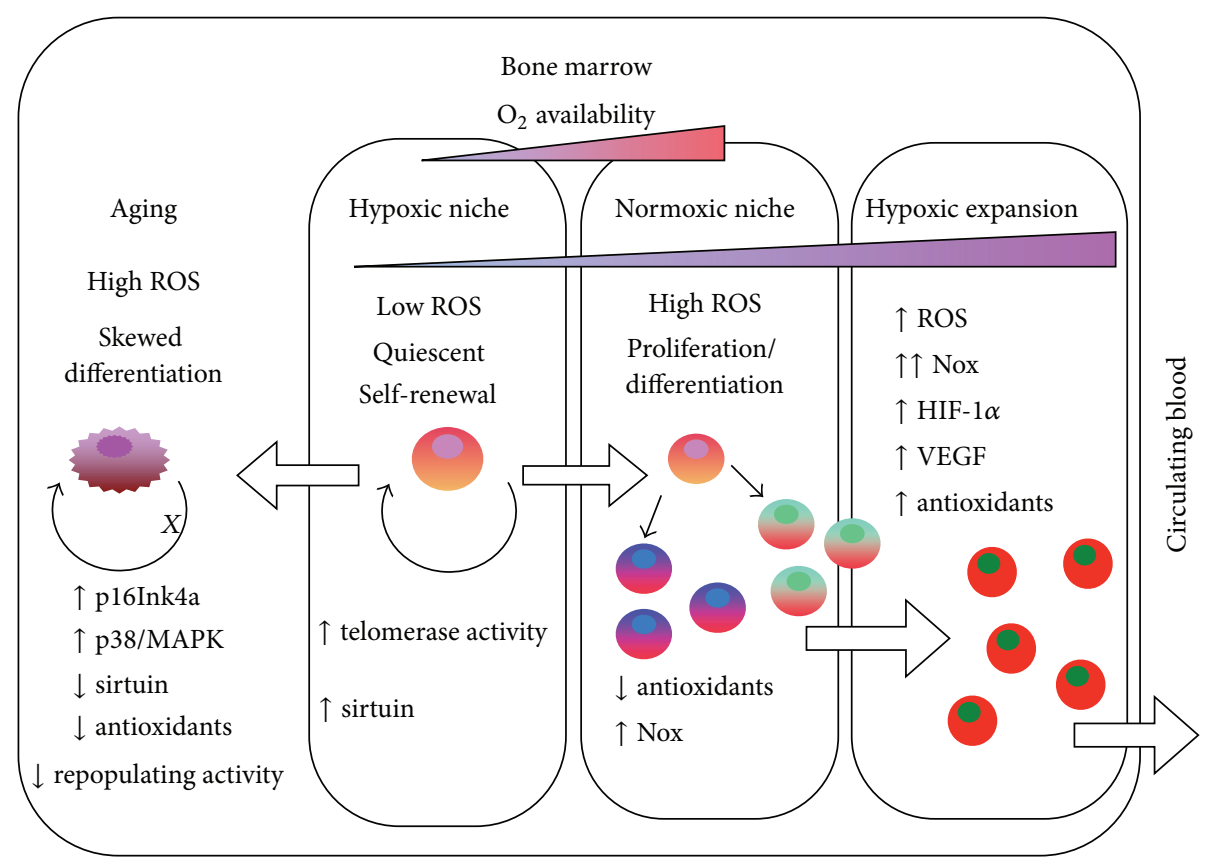

FIGURE 2: Schematic diagram of bone marrow microenvironment (Niche). Stem cells with self-renewal capacity reside in the hypoxic niche where the levels of reactive oxygen species (ROS) are low. Proliferation and differentiation of stem cells occur at the oxygenic niche where higher levels of ROS promote cell differentiation. During ischemia, hypoxic expansion upregulates transcription factor and hypoxia inducible factor-1 $\alpha$ (HIF-1 $\alpha$ ), increasing the levels of vascular endothelial growth factor (VEGF) expression in the bone marrow. Meanwhile, there is an increase in NADPH oxidase- (Nox-) mediated ROS production. With aging, stem cells loss their self-renewal ability and displayed a skewed differentiation pattern (for details please see text).

supply and demand. Demonstrated by in vivo injection of $\mathrm{O}_{2}{ }^{--}$reactive dye, dihydroethidium (DHE), Urao et al. 2012 show that hindlimb ischemia induces ROS production in both the endosteal and central regions of the entire bone marrow in situ. In conjunction with the increase in ROS levels, hindlimb ischemia also induces hypoxic expansion in bone marrow microenvironment [67]. The spatial distribution of hypoxia in bone marrow is visualized by an in vivo injection of hypoxic bioprobe, pimonidazole, that detects area less than $1.3 \% \mathrm{O}_{2}$ by cross-linking protein adducts at oxygen tension below $10 \mathrm{mmHg}$ [68]. These changes in the bone marrow microenvironment lead to upregulation of hypoxia-inducible factor- $1 \alpha$ (HIF- $1 \alpha$ ) and vascular endothelial growth factor (VEGF) throughout the bone marrow (Figure 2). The mechanisms of how a distal ischemia in the hindlimb is capable of inducing an increase in ROS and hypoxic expansion in the bone marrow are yet fully understood. Nevertheless, Nox2 deficiency abolishes ischemia-induced hypoxic expansion and HIF- $1 \alpha$ expression in the bone marrow microenvironment. Moreover, the levels of circulating EPC-like c-kit+/Flk1+ cells or c-kit+/Linprogenitor cells are decreased in Nox2-/- mice following hindlimb ischemia $[67,69]$. Therefore, Nox2-derived ROS induces hypoxic expansion and HIF-1 $\alpha$ expression in the bone marrow microenvironment, which plays a role in progenitor cell expansion and mobilization into the circulating blood following ischemia.

The components of NADPH oxidase are expressed in various stem and progenitor cells including human bone marrow-derived CD34+ cells [70, 71], mouse embryonic stem cells [63], skeletal muscle precursor cells [71], and rat mesenchymal stem cells [72]. The constitutively active NADPH oxidase generates low levels of $\mathrm{H}_{2} \mathrm{O}_{2}$ in HSCs, which in turn stabilizes HIF- $1 \alpha$ expression by inhibiting prolyl hydroxylases- (PHD-) mediated degradation of HIF$1 \alpha$ under normoxic conditions. An increase in HIF- $1 \alpha$ expression is found in granulocyte colony stimulating factor(G-CSF-) mobilized CD133+ and CD34+ HSCs from the peripheral blood of healthy donors [71, 73]. ROS-mediated HIF-1 $\alpha$ stabilization may offer an advantage of enhancing the proangiogenic and antioxidative potential of the mobilizing bone marrow HSCs prior to homing to the hypoxic tissues, thereby facilitating neovascularization and tissue repair.

Interestingly, populations of more committed progenitor cells are intrinsically less sensitive to the elevation of intracellular ROS levels compared to HSCs. Serial transplantation of human Lin-/CD34+/CD38- HSCs into immunodeficient mice triggers replicative stress-induced elevation of intracellular ROS and leads to HSC premature senescence due to persistent DNA damage. However, Lin-/CD34+/CD38+ progenitor cells are more resistance to oxidative DNA damage [74]. Human EPCs isolated from peripheral blood followed by a short term ex vivo culture (4 days) exhibit low intracellular levels of $\mathrm{H}_{2} \mathrm{O}_{2}$ and $\mathrm{O}_{2}{ }^{\cdot-}$. The expressions of antioxidative enzymes, such as manganese superoxide dismutase (MnSOD), catalase, and glutathione peroxidase, are higher in EPCs compared to mature endothelial cells (ECs). Furthermore, the intracellular levels of ROS remain stable when 
TABLE 2: Summary of distinctive features of stem and progenitor cells.

\begin{tabular}{|c|c|}
\hline Cell type & Features and functions \\
\hline \multicolumn{2}{|c|}{ Hematopoietic stem cells (HSCs) } \\
\hline & $\begin{array}{l}\text { Lineage depleted, viable (annexin negative), undifferentiated, and primitive } \\
\text { multipotential hematopoietic stem cells }\end{array}$ \\
\hline Lin-/CD34+/AnV- & ROS $^{\text {low }}$ : self-renewal, $\uparrow$ telomerase \\
\hline & ROS $^{\text {high }}:$ limited self-renewal, $\uparrow p 16$ Ink $4 a, \uparrow p 38 / M A P K$ \\
\hline \multirow{3}{*}{ Lin-/CD34+/CD38- } & $\begin{array}{l}\text { Lineage depleted, undifferentiated, and primitive multipotential hematopoietic } \\
\text { stem cells }\end{array}$ \\
\hline & ROS sensitive \\
\hline & $\begin{array}{l}\text { Serial transplantation of Lin-/CD34+/CD38- leads to DNA damage and } \\
\text { premature senescence }\end{array}$ \\
\hline \multicolumn{2}{|r|}{$\begin{array}{l}\text { Lineage depleted, primitive hematopoietic/lymphoid stem cells } \\
\text { Less sensitive to ROS elevation and resistant to oxidative DNA damage }\end{array}$} \\
\hline \multirow[t]{6}{*}{ Scal+/c-kit+/Lin- } & $\begin{array}{l}\text { Primitive stem cells } \\
\text { Mobilized into circulation via increasing ROS in response to ischemia }\end{array}$ \\
\hline & nic stem cells (ES) \\
\hline & Active in proliferation and differentiation \\
\hline & Require low levels of $\mathrm{H}_{2} \mathrm{O}_{2}$ to trigger cardiomyogenesis \\
\hline & $\uparrow$ Nox $1, \uparrow$ Nox 2 , and $\uparrow$ Nox 4 \\
\hline & $\downarrow$ Antioxidative and stress resistance genes \\
\hline \multicolumn{2}{|r|}{ Progenitor cells } \\
\hline Endothelial progenitor cells (EPCs) & $\begin{array}{l}\text { Ex vivo cultured for } 4 \text { days } \\
\uparrow \text { MnSOD, } \uparrow \text { catalase, and } \uparrow \text { glutathione peroxides } \\
\text { Stable intracellular ROS levels } \\
\text { Resistance to ROS-induced apoptosis }\end{array}$ \\
\hline Late-outgrowth endothelial cells (OECs) & $\begin{array}{l}\text { Ex vivo cultured for } 2-3 \text { weeks } \\
\uparrow M n S O D \\
\text { Similar levels of CuZnSOD and catalase compared to mature endothelial cells }\end{array}$ \\
\hline
\end{tabular}

EPCs are exposed to a redox cycler, napthoquinolinedione, that generates $\mathrm{H}_{2} \mathrm{O}_{2}$ and $\mathrm{O}_{2}{ }^{\cdot-}$. EPCs are also less sensitive to ROS-induced apoptosis compared to mature endothelial cells [75]. In another study, $\mathrm{He}$ et al. 2004 reported that catalase and CuZnSOD enzymatic activities are similar between EPCs and mature ECs and that mitochondrial MnSOD is the most likely of the three antioxidants to be responsible for EPC resistance to oxidative stress [76]. The discrepancy in antioxidant upregulation between the two studies may be due to the methodology of EPC culture and the definition of EPCs. In Dernbach et al. study, EPCs were cultured for 4 days and are characterized by an uptake of acetylated low-density lipoprotein (Dil-Ac-LDL) and lectin [77]. On the other hand, EPCs were cultured for an extended period, 2-3 weeks, and displayed cobblestone phenotype in $\mathrm{He}$ et al. study. In fact, the term "EPCs" in He et al. study may be better described as late-outgrowth endothelial cells (OECs). Demonstrated by Sieveking et al. 2008, EPCs and OECs have distinctive differences in angiogenic properties [78]. Therefore, it is speculated that the levels of antioxidative defense may be fine-tuned depending on functions and status of progenitor cells. OECs may require a higher tolerance toward mitochondrial oxidative stress and maintain mitochondrial structure integrity, which lessens the need for cytosolic antioxidants compared to EPCs. Features of stem and progenitor cells are summarized in Table 2.

ROS generation from the ischemic tissues also plays a role in promoting stem and progenitor cell mobilization. For example, ischemic skeletal muscles increase the production of hematopoietic cytokines, such as interleukin-3 and erythropoietin, which induce a rapid and transient ROS production. Subsequently, these cytokines promote bone marrow progenitor cells exiting quiescence through G1 to $\mathrm{S}$ cell cycle progression [79]. Stromal cell-derived factor-1 (SDF1) released in ischemic tissue promotes stem and progenitor cell mobilization into the circulation by binding to $\mathrm{C}-\mathrm{X}-\mathrm{C}$ motif receptor 4 (CXCR4) [80]. SDF-1-induced chemotaxis is regulated by c-Met activation [81], which is known to control complex biological program of "invasive growth" and tumor spreading [82]. Activation of c-Met induces mTOR signaling 


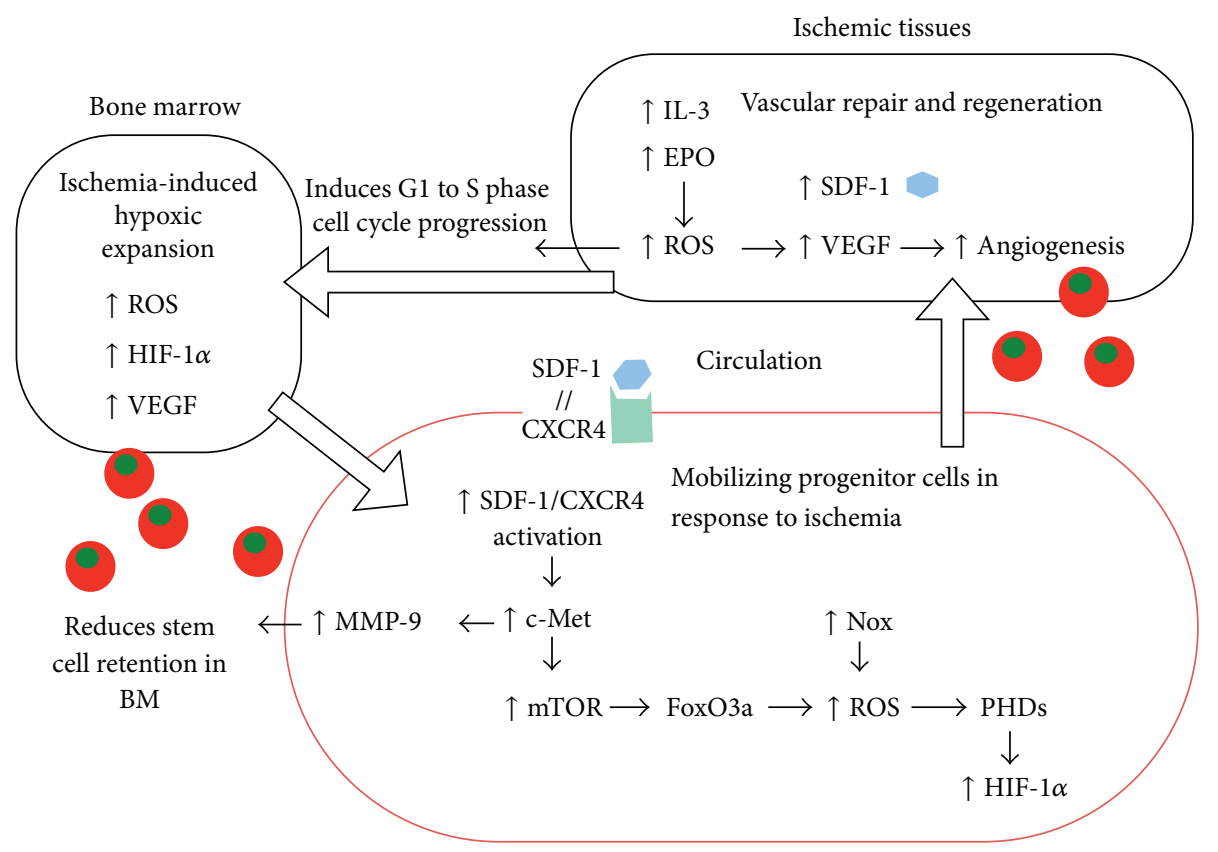

FIGURE 3: Schematic diagram of mechanisms involved in ischemia-induced progenitor cell mobilization. Under ischemic conditions, stromal cell-derived factor-1 (SDF-1) and hematopoietic cytokines, such as interleukin-3 (IL-3) and erythropoietin (EPO), are released from the tissues. Hematopoietic cytokines increase ROS and induce G1 to S phase cell cycle progression. Meanwhile, ischemia induces hypoxic expansion in the bone marrow to promote cell proliferation and differentiation (see Figure 2). In the circulation, SDF-1 binds to progenitor cells (outlined as red) expressing its receptor, CXCR4. SDF-1/CXCR4 activation induces c-Met and mTOR leads to downregulation of FoxO3a and increase in ROS production. Activation of c-Met upregulates the expression of matrix metalloproteinase-9 (MMP-9), which inhibits the adhesive interaction of progenitor cells to bone marrow (BM). In addition, NADPH oxidase (Nox) promotes ROS formation, which in turn stabilizes the levels of hypoxia inducible factor- $1 \alpha$ (HIF-1 $\alpha$ ) by inhibiting prolyl hydroxylases (PHD). The mobilized progenitor cells facilitate the vascular repair and regeneration at the ischemic tissues.

and downregulates the levels of FoxO3a, which belong to the Forkhead Box, class O (FoxO) family of transcription factors that regulates oxidative stress. As a result, c-Met activation promotes the G-CSF-induced mobilization of bone marrow primitive progenitor cells (Scal+/c-Kit+/Lin-) via increasing levels of ROS and upregulates the expression of proteolytic enzyme matrix metalloproteinase-9 (MMP-9) [81]. MMP-9 enhances progenitor cell mobilization into the circulation by inhibiting adhesive interaction necessary to retain stem and progenitor cells within the bone marrow [83] (Figure 3). Although it is beyond the scope of this review, low levels of ROS generated in the tissues during ischemic injury also promote local angiogenesis. The expressions of many angiogenic genes, such as VEGF, fibroblast growth factor, platelet-derived growth factor, and receptors are likely to be regulated by redox signaling [84]. Nox2-derived ROS is involved in VEGF signaling, which plays an important role in EC migration and proliferation, as well as reparative angiogenesis in response to hindlimb ischemia in vivo [85, 86].

\section{Stem and Progenitor Cell Aging}

With aging, stem cells lose self-renewal activity and terminally differentiated, thereby exiting the stem cell pool. On the other hand, they may undergo apoptosis or senescence induced by higher levels of ROS (Figure 2). Age-related depletion of stem cell pool may be driven by an imbalance of intracellular ROS that regulates stem cell quiescence and proliferation. Aged mice have a decrease in ROS $^{\text {low }}$ population of Lin-/CD34+/AnV- cells, indicating a reduction of HSC populations that are capable of more durable long-term self-renewal [57]. HSCs from elderly individuals also exhibit higher levels of ROS and have reduced ability to reconstitute hematopoiesis of murine host compared with HSCs from middle-aged individuals [74]. Aged HSCs display a skewed differentiation potential, in which these cells overproduce myeloid lineage cells rather than a multilineage population, consisting of both myeloid and lymphoid lineage cells [57, 60, 87].

The sirtuin family of NAD-dependent deacetylases, a key regulator of organismal longevity, has been shown to modulate stem cell aging. Deletion of SIRT1 in young HSCs displays an aging phenotype with a skewed differentiation toward myeloid lineage that is associated with a decline in lymphoid compartment [88]. Lentiviral shRNA knockdown of SIRT1 in human bone marrow-derived mesenchymal stem cell accelerates cellular senescence [89]. Recently, a link between oxidative metabolism and sirtuin in modulating stem cell homeostasis has been reported. Brown et al. 2013 show that 
SIRT3 is downregulated with age and is accompanied with a reduction of mitochondrial MnSOD activity which in turn contributes to increased ROS levels in aged HSCs. Demonstrated by an in vivo competitive transplantation assay, it is showed that SIRT3 is required to maintain HSC pool size and regenerative capacity under oxidative stress conditions, such as aging and serial transplantation [90]. SIRT3 preserves HSC functions by enhancing mitochondrial MnSOD antioxidative activity via posttranslational deacetylation of critical lysine residues [90, 91]. Furthermore, SIRT3 has a critical role in bone marrow cell-mediated cardiac repair. It is shown that intramyocardial injection of bone marrow cells from SIRT3 knockout mice results in reduced numbers of Scal+/c-kit+ progenitor cells mobilized to the ischemic area following myocardial infarction. The loss of SIRT3 increases ROS formation and cellular apoptosis, reducing the proangiogenic capability in EPCs in vitro [92].

Bioactive peptides in the vascular system also play a role in progenitor cell aging. Angiotensin II (Ang II) is a key effector of the renin-angiotensin system. Ang II not only regulates blood pressure as a potent vasoconstrictor, but also promotes inflammation, hypertrophy, and fibrosis. Ang II plays a role in vascular damage and remodeling in cardiovascular diseases [93-95]. It has been demonstrated that inhibition of angiotensin-converting enzyme by Ramipril augments circulating EPCs with enhanced functional activity in patients with stable coronary artery disease [96]. In human EPCs, Ang II increases the expression of Nox2 component, gp91phox, and accelerates the onset EPC senescence through an induction of oxidative stress, as evidenced by peroxynitrite formation in vitro. Pretreatment of EPC with SOD prevents Ang II-induced telomerase inactivation [97]. Hepatocyte growth factor (HGF) also attenuates Ang II-induced EPC senescence by reducing gp91phox expression and limiting the production of $\mathrm{O}_{2}{ }^{--}$in EPCs [98].

Excessive production of ROS in pathological conditions has been associated with HSC exhaustion. "Ataxia telangiectasia mutated" (Atm) gene is responsible for genomic stability in response to DNA damage and oxidative stress. Mice with Atm deficiency (Atm-/-) exhibit progressive bone marrow failure in association with increased ROS levels [99]. The elevation of ROS induces p38/MAPK phosphorylation in HSCs and is accompanied by a defect in maintaining HSC quiescence. Treatment of Atm-/- mice with antioxidant NAC restores the HSC reconstitutive capacity and prevents bone marrow failure [61]. Loss of FoxO3a in HSCs also results in elevated oxidative stress, increased p38/MAPK phosphorylation, and defective maintenance of quiescence. The ability of HSCs to support long-term reconstitution of HSC pool in a competitive transplantation assay is impaired in FoxO3a-/- mice [100]. Conditional deletion of FoxO1, FoxO3a, and FoxO4 in mouse hematopoietic system leads to increased ROS levels, myeloid lineage expansion, and a reduction in Lin-/Scal+/c-kit+ HSC population [101]. Indisputably, excessive ROS production is associated with the disruption of HSC quiescence and impairment in hematopoietic repopulating ability of HSCs in the bone marrow.

\section{Unbalanced ROS Levels and Age-Related Impairment in Ischemia-Induced Neovascularization}

The importance of balanced ROS levels in mediating ischemia response and neovascularization has been demonstrated in animal models manipulated to have impaired cellular antioxidant mechanisms. Heterozygous knockout of mitochondrial MnSOD results in an increased lipid peroxidation and a defect in myocardial contractile function followed by ischemia-reperfusion injury in isolated heart, while deletion of a single copy of cytosolic CuZnSOD does not show any significant impairment [102]. This suggests that there is a tissue-specific requirement of antioxidative enzyme in the tolerance to oxidative stress that cannot be compensated by the other SOD isoforms. Studies have also demonstrated a differential effect of aging on ROS-mediated ischemic response. Carotid arteries from young heterozygote $\mathrm{CuZn-}$ SOD (+/-) knockout mice show no significant alternation in endothelial relaxation in response to acetylcholine. However, aged CuZnSOD (+/-) mice are impaired in endothelialdependent vasodilation in response to acetylcholine, which can be restored by the presence of superoxide scavenger, tempol [103]. The effect of a single deletion of CuZnSOD is minimal in young age. ROS seem to be well tolerated in young cells with highly proficient antioxidative defense, which may be compensated by the remaining copy of CuZnSOD and other antioxidative enzymes. With aging, cells with less efficient antioxidative defense become sensitive to oxidative stress, which aggravates ROS formation. Eventually, aged cells are inadequate to maintain proper vascular functions. On the other hand, young homozygous CuZnSOD (-/-) knockout mice exhibit an accelerated vascular aging and impaired ischemia-induced neovascularization. Young CuZnSOD-/mice have similar oxidative stress levels in the ischemic tissues as those observed in older wild type littermate, examined by immunofluorescence staining of DHE and nitrotyrosine (an indicator of protein nitration by ROS). Aged CuZnSOD-/- mice have the highest level of oxidative stress and display severe necrosis and autoamputation in the second weeks after surgically induced hindlimb ischemia [104]. CuZnSOD deficiency leads to increased ROS levels and is associated with reduced proangiogenic functions of EPCs, such as migratory ability and integration into endothelial cell tubules in vitro [105]. The peripheral EPC levels in the spleen are lower in both young and aged CuZnDOS-/mice [104]. Authors suggest that CuZnSOD deficiency may cause a depletion of EPC reserve in the bone marrow and result in the impaired EPC mobilization observed in the spleen of CuZnSOD-/- mice. However, EPC levels in the bone marrow of CuZnSOD-/- mice and whether CuZnSOD deficiency attenuates EPC mobilization from the bone marrow to the circulating blood remained to be determined. Nevertheless, aging exacerbates oxidative stress-associated EPC dysfunction in the absence of CuZnSOD. CuZnSOD has a critical role in limiting excessive ROS accumulation and preserves EPC angiogenic activities with aging. The role of CuZnSOD in modulating EPC numbers and functional 
TABLE 3: Selected cell-based preclinical studies.

\begin{tabular}{|c|c|c|c|}
\hline Cell treatment & Ischemic model & Outcomes & References \\
\hline $\begin{array}{l}\text { Ex vivo culture expanded human } \\
\text { EPCs from healthy young } \\
\text { individuals }\end{array}$ & $\begin{array}{l}\text { Myocardial ischemia in } \\
\text { athymic nude mice }\end{array}$ & $\begin{array}{l}\text { Increased neovascularization; increased capillary } \\
\text { density; reduced infarct size; improved LV function } \\
\text { after myocardial ischemia }\end{array}$ & {$[25]$} \\
\hline $\begin{array}{l}\text { Human peripheral blood } \\
\text { MNC-derived CD14+ or CD14- } \\
\text { EPCs }\end{array}$ & $\begin{array}{l}\text { Hindlimb ischemia in athymic } \\
\text { nude mice }\end{array}$ & Increased blood perfusion; increased capillary density & {$[26]$} \\
\hline $\begin{array}{l}\text { Human blood-derived CD34+ } \\
\text { cells }\end{array}$ & $\begin{array}{l}\text { Hindlimb ischemia in diabetic } \\
\text { mice }\end{array}$ & $\begin{array}{l}\text { Increased blood flow perfusion in diabetic mice, but } \\
\text { not in nondiabetic mice }\end{array}$ & [27] \\
\hline $\begin{array}{l}\text { Human blood cord-derived } \\
\text { CD34+ EPCs }\end{array}$ & Cerebral ischemia in mice & $\begin{array}{l}\text { Accelerated neovascularization of infarct neuronal } \\
\text { tissue; increased cortical expansion; increased neuronal } \\
\text { regeneration; improved recovery of motor deficits }\end{array}$ & {$[28]$} \\
\hline $\begin{array}{l}\text { Ex vivo expanded human EPCs } \\
\text { from peripheral blood followed } \\
\text { by VEGF transduction }\end{array}$ & $\begin{array}{l}\text { Hindlimb ischemia in athymic } \\
\text { nude mice }\end{array}$ & $\begin{array}{l}\text { Reduced limb loss; increased blood flow recovery after } \\
\text { ischemia; increased EPC incorporation in vivo }\end{array}$ & [29] \\
\hline $\begin{array}{l}\text { Autologous EPCs from } \\
\text { peripheral blood }\end{array}$ & $\begin{array}{l}\text { Pulmonary hypertension in } \\
\text { dogs }\end{array}$ & $\begin{array}{l}\text { Improved pulmonary artery pressure, cardiac output, } \\
\text { and pulmonary vascular resistance }\end{array}$ & {$[30]$} \\
\hline $\begin{array}{l}\text { Autologous EPCs from } \\
\text { peripheral blood }\end{array}$ & Carotid denudation in rabbits & $\begin{array}{l}\text { Accelerated reendothelialization; improved endothelial } \\
\text { function }\end{array}$ & {$[31]$} \\
\hline $\begin{array}{l}\text { Autologous CD34+ EPCs from } \\
\text { bone marrow }\end{array}$ & $\begin{array}{l}\text { Acute myocardial infarction } \\
\text { in macaques }\end{array}$ & $\begin{array}{l}\text { Improved regional blood flow; increased capillary } \\
\text { density in the peri-infarct region; improved cardiac } \\
\text { function; increased VEGF and bFGF levels in } \\
\text { peri-infarct region }\end{array}$ & {$[32]$} \\
\hline
\end{tabular}

MNC, mononuclear cell.

VEGF, vascular endothelial growth factor.

bFGF, basic fibroblast growth factor.

activities may also have important clinical implications. Patients with chronic heart failure and coronary artery disease have lower levels of antioxidant enzymes, including CuZnSOD [106, 107], which may explain reduced EPC numbers and functions in patients $[23,108]$. Alternatively, protection against age-dependent impairment in ischemiainduced neovascularization in association with excessive ROS formation has been demonstrated in Nox2 deficient mice. Nox 2 deficiency ameliorates age-related increase in ROS levels and enhances bone marrow-derived EPC proangiogenic functions in vitro. As a result, aged Nox2-/- mice exhibit enhanced blood flow recovery following ischemia [109]. As the tolerance of oxidative stress decreases with age, it is essential to preserve stem and progenitor cell vasculogenic functions by maintaining ROS balance.

\section{Therapeutic Potential of Cell-Based Therapy for Age-Related Impairment in Neovascularization by Modulating Redox Regulation}

Implantation of autologous bone marrow-derived stem and progenitor cells is a potential treatment for ischemic diseases. Cell-based therapies have been safely conducted and demonstrated beneficial effects in augmenting neovascularization in preclinical animal studies (Table 3). Despite the promise of preclinical studies, human clinical trials involving an administration of autologous bone marrow cells or progenitor cells from bone marrow or peripheral blood have, to date, yielded neutral or underwhelming outcomes (Table 4). In experimental settings, stem and progenitor cells are often isolated from healthy young animals as donors and transplanted into young healthy recipients. The isolated stem cells are often highly regenerative and may contain less cumulative ROSrelated damage. However, patients who would undergo cellbased therapy are elderly who have increased ROS levels and reduced numbers of stem and progenitor cells with impaired regenerative potential.

Studies have investigated different approaches to enhance the therapeutic potential of stem and progenitor cells by modulating their redox regulation. The first strategy involved suppressing excessive oxidative stress by promoting the antioxidative potential. For example, transgenic expression of MnSOD or administration of SOD mimic rescues impaired postischemia neovascularization and tissue survival in diabetic mice [110, 111]. Mesenchymal stem cell engraftment in the infarct heart is enhanced by coinjection of antioxidant NAC which mitigates ROS-induced inhibition of cell-matrix adhesion [112]. Intraperitoneal injection of SOD mimic reduces ROS formation and facilitates CD34+ progenitor cell recruitment to the infarct heart following coronary ligation in mice [113]. Preconditioning stem cells, with either a brief period of ischemia/anoxia or repeated cycles of intermittent hypoxia/reoxygenation, increase postengraftment cell survival or neovascular potential through oxidative stress resistance mechanism [114]. Electrical stimulation also provides preconditioning effect on the survival of cardiac stem cells and protects against oxidative stress-induced apoptosis via AKT activation by downregulating miR-378 [115]. Another 
TABLE 4: Selected human cell-based clinical studies.

\begin{tabular}{|c|c|c|c|c|c|}
\hline Conditions & Cell type & Therapy & Delivery methods & Outcome & Reference \\
\hline \multirow{10}{*}{$\begin{array}{l}\text { Acute myocardial } \\
\text { infarction }\end{array}$} & $\mathrm{BMC}$ & $\begin{array}{l}\text { BOOST } \\
\text { (randomized } \\
\text { controlled) }\end{array}$ & $\begin{array}{l}\text { Intracoronary } \\
\text { injection }\end{array}$ & $\begin{array}{l}\text { Improvement in LVEF at } 6 \text {-month } \\
\text { follow-up, but it failed to sustain the } \\
\text { functional enhancement at } 18 \text {-month and } \\
5 \text {-year follow-ups }\end{array}$ & {$[33]$} \\
\hline & $\mathrm{BMC}$ & $\begin{array}{l}\text { REPAIR-AMI } \\
\text { (randomized } \\
\text { controlled) }\end{array}$ & $\begin{array}{l}\text { Intracoronary } \\
\text { infusion }\end{array}$ & $\begin{array}{l}\text { Improved LVEF at 4-month follow-up; } \\
\text { improvement of LV function sustained at } \\
12 \text {-month follow-up and reduced major } \\
\text { adverse CV events }\end{array}$ & [34-36] \\
\hline & $\mathrm{BMC}$ & $\begin{array}{l}\text { STEMI } \\
\text { (randomized } \\
\text { controlled) }\end{array}$ & $\begin{array}{l}\text { Intracoronary } \\
\text { infusion within } 24 \mathrm{~h} \\
\text { administration }\end{array}$ & $\begin{array}{l}\text { Reduced infarct size, but no significant } \\
\text { improvement in LV function at 4-month } \\
\text { follow-up }\end{array}$ & {$[37]$} \\
\hline & $\mathrm{BMC}$ & $\begin{array}{l}\text { ASTAMI } \\
\text { (randomized } \\
\text { controlled) }\end{array}$ & $\begin{array}{l}\text { Intracoronary } \\
\text { injection }\end{array}$ & $\begin{array}{l}\text { No changes in LV end-diastolic volume } \\
\text { or infarct size at } 6 \text {-month follow-up }\end{array}$ & {$[38]$} \\
\hline & BMC & $\begin{array}{l}\text { BALANCE } \\
\text { (controlled but } \\
\text { nonrandomized) }\end{array}$ & $\begin{array}{l}\text { Intracoronary } \\
\text { infusion }\end{array}$ & $\begin{array}{l}\text { Improved LV function, contractility, } \\
\text { infarct size, haemodynamics, and exercise } \\
\text { capacity at } 12 \text { - and } 60 \text {-month follow-up }\end{array}$ & {$[39]$} \\
\hline & $\begin{array}{l}\text { CD133+ progenitor } \\
\text { cells }\end{array}$ & $\begin{array}{l}\text { Small scale; } \\
\text { nonrandomized }\end{array}$ & $\begin{array}{l}\text { Intracoronary } \\
\text { infusion }\end{array}$ & $\begin{array}{l}\text { Improved LVEF at } 4 \text {-month follow-up } \\
\text { but increased incident of coronary events }\end{array}$ & {$[40,41]$} \\
\hline & $\begin{array}{l}\text { CD133+ progenitor } \\
\text { cells }\end{array}$ & $\begin{array}{l}\text { Small scale; } \\
\text { nonrandomized }\end{array}$ & $\begin{array}{l}\text { Transplantation to } \\
\text { peri-infract zone } \\
\text { during CABG surgery }\end{array}$ & $\begin{array}{l}\text { Improvements in myocardial viability } \\
\text { and local perfusion; no adverse events at } \\
6 \text {-month follow-up }\end{array}$ & {$[42]$} \\
\hline & $\begin{array}{l}\text { BMC and } \\
\text { BM-derived } \\
\text { CD34+/CXCR4+ } \\
\text { progenitor cells }\end{array}$ & REGENT & $\begin{array}{l}\text { Intracoronary } \\
\text { infusion }\end{array}$ & $\begin{array}{l}\text { Increased LVEF; no significant } \\
\text { differences in absolute changes of LVEF } \\
\text { between groups at 6-month follow-up }\end{array}$ & {$[43]$} \\
\hline & BM-derived MSCs & $\begin{array}{l}\text { Randomized } \\
\text { controlled }\end{array}$ & Intravenous injection & $\begin{array}{l}\text { Increased LVEF; improved global } \\
\text { symptom at 6-month follow-up; MSCs } \\
\text { traps in pulmonary passage in animal } \\
\text { model }\end{array}$ & {$[44,45]$} \\
\hline & $\begin{array}{l}\text { BMC and } \\
\text { circulating } \\
\text { blood-derived } \\
\text { CD34+ progenitor } \\
\text { cells }\end{array}$ & $\begin{array}{l}\text { TOPCARE-AMI } \\
\text { (randomized } \\
\text { controlled) }\end{array}$ & $\begin{array}{l}\text { Intracoronary } \\
\text { infusion }\end{array}$ & $\begin{array}{l}\text { Improvement in LVEF at 3-month } \\
\text { follow-up; effect of BMC transplantation } \\
\text { is greater than CPC; functional } \\
\text { improvements sustained for } 2 \text { years }\end{array}$ & {$[46,47]$} \\
\hline $\begin{array}{l}\text { Ischemic } \\
\text { cardiomyopathy }\end{array}$ & $\begin{array}{l}\text { Autologous skeletal } \\
\text { myoblasts }\end{array}$ & $\begin{array}{l}\text { MAGIC } \\
\text { (randomized } \\
\text { controlled) } \\
\end{array}$ & $\begin{array}{l}\text { Injection around the } \\
\text { scar tissues }\end{array}$ & $\begin{array}{l}\text { No significant improvement in global and } \\
\text { regional LV function; an increase in } \\
\text { arrhythmic events in treated patients }\end{array}$ & {$[48]$} \\
\hline $\begin{array}{l}\text { Chronic heart } \\
\text { failure }\end{array}$ & Bone marrow cells & STAR & $\begin{array}{l}\text { Intracoronary } \\
\text { infusion }\end{array}$ & $\begin{array}{l}\text { Improvements in LV function, exercise } \\
\text { capacity, and oxygen uptake over a 5-year } \\
\text { follow-up }\end{array}$ & [49] \\
\hline \multirow{2}{*}{$\begin{array}{l}\text { Refractory } \\
\text { myocardial } \\
\text { ischemia }\end{array}$} & Bone marrow cells & $\begin{array}{l}\text { (Randomized } \\
\text { controlled) }\end{array}$ & $\begin{array}{l}\text { Intramyocardial } \\
\text { injection }\end{array}$ & $\begin{array}{l}\text { Improvement of myocardial perfusion, } \\
\text { angina severity, and quality of life at } \\
\text { 3-month follow-up }\end{array}$ & {$[50]$} \\
\hline & $\begin{array}{l}\text { CD34+ progenitor } \\
\text { cells }\end{array}$ & $\begin{array}{l}\text { ACT34-CMI } \\
\text { (randomized } \\
\text { controlled) }\end{array}$ & $\begin{array}{l}\text { Intramyocardial, } \\
\text { transendocardial } \\
\text { injection }\end{array}$ & $\begin{array}{l}\text { Improvement in angina frequency and } \\
\text { exercise tolerance }\end{array}$ & {$[51,52]$} \\
\hline $\begin{array}{l}\text { Severe coronary } \\
\text { artery diseases }\end{array}$ & Bone marrow cells & $\begin{array}{l}\text { PROTECT-CAD } \\
\text { (randomized } \\
\text { controlled) }\end{array}$ & $\begin{array}{l}\text { Endomyocardial } \\
\text { injection }\end{array}$ & $\begin{array}{l}\text { Improved LV function, exercise time, and } \\
\text { NYHA functional class at } 6 \text {-month } \\
\text { follow-up }\end{array}$ & {$[53]$} \\
\hline
\end{tabular}

BMC, bone marrow cells.

LVEF, LV ejection fraction.

MI, myocardial infarction.

NYHA, New York Heart Association.

CABG, coronary artery bypass grafting.

MSC, mesenchymal stem cell. 
approach involved stimulating stem cells with low-dose of prooxidants. Short-term treatment of mouse bone marrow cells with $5 \mu \mathrm{M} \mathrm{H}_{2} \mathrm{O}_{2}$ for 30 min enhances their angiogenic potency by promoting VEGF production and endothelial differentiation [116]. In vitro treatment of adipose-derived stroma cells (ADSCs) with pharmacological inhibitors to generate mitochondrial ROS increases the secretion of proangiogenic factors and protects ADSCs against ROS-induced apoptosis. Furthermore, in vivo injection of the treated ASCs promotes neovascularization in hindlimb ischemia [117]. Although most of these enhancements are demonstrated in cells from young donors and recipients, some have been shown effective in aged cells and old recipients. For example, preconditioning of bone marrow cells from aged mice (20-22 months old), by culturing cells at $2 \% \mathrm{O}_{2}$ for 24 hours, shows enhanced adhesion, survival, and proangiogenic potential in vitro. The preconditioned cells augment ischemia-induced neovascularization in aged mice following intramuscular injection [118]. Hypoxic preconditioning of human ADSCs from donor over 50 years old at $0.5 \% \mathrm{O}_{2}$ for 24 hours increases redox metabolism and promotes paracrine secretion [119]. Treatment of bone marrow-derived angiogenic cells from aged mice (17 months old) with dimethyloxalylglycine (DMOG), an $\alpha$-ketoglutarate antagonist, induces HIF- $1 \alpha$ that leads to metabolic reprogramming and decreases ROS formation in these aged cells. In combination with HIF$1 \alpha$ gene therapy in the ischemic muscle tissues, intravenous injection of DMOG-treated cells prevents limb necrosis and autoamputation in old recipients mice following ischemia [120]. While there are many strategies that modulate the redox regulation of stem and progenitor cells, it is essential for in vitro and preclinical studies to consider the clinical scenario, where elderly patients often suffer from comorbidities that affect neovascularization, such as diabetes, hypercholesterolemia, and advanced atherosclerosis. Therefore, it may be beneficial to develop cell-based therapies targeting combined pathophysiological conditions such as aging, metabolic disorders, and inflammatory diseases.

\section{Conclusion}

ROS production and aging are intertwined biological events that play a critical role in vascular repair and regeneration. ROS are intrinsic regulators that are involved in maintaining the abilities of self-renewal of stem cells and their differentiation into "lineage-committed" progenitor cells. The levels of ROS are attuned by the balance between ROS generation and antioxidative defense systems, depending on the cellular functions at different stages of stem and progenitor cells. On the other hand, ROS are extrinsic mediators that modulate bone marrow microenvironment in low-oxygen tension and induce hypoxic expansion in response to ischemic injury. Aging is associated with an increase in oxidative stress, in which the unbalanced ROS levels further contribute to cell aging. The age-dependent impairment in ischemia-induced neovascularization is, partly, due to oxidative stress-related dysfunction of stem and progenitor cells. Understanding the molecular targets of ROS and distinct redox signaling pathways in stem and progenitor cell function as well as how aging alters the redox balance will enable us to improve the efficacy of cell-based therapies and to better accommodate cardiovascular disease in aging populations.

\section{Abbreviations}

Ang II: Angiotensin II

CuZnSOD: Copper-zinc superoxide dismutase

CXCR4: C-X-C motif receptor 4

DHE: Dihydroethidium

EPC: $\quad$ Endothelial progenitor cell

FoxO: $\quad$ Forkhead Box class $\mathrm{O}$

G-CSF: Granulocyte colony stimulating factor

HIF-1 $\alpha$ : Hypoxia-inducible factor- $1 \alpha$

HSC: Hematopoietic stem cell

MAPK: Mitogen-activated protein kinase

MnSOD: Manganese superoxide dismutase

NAC: N-Acetyl-L-cysteine

Nox: $\quad$ NADPH oxidase

SDF-1: $\quad$ Stromal cell-derived factor-1

SIRT: $\quad$ Sirtuin

VEGF: Vascular endothelial growth factor.

\section{Conflict of Interests}

The author declares that there is no conflict of interests regarding the publication of this paper.

\section{Acknowledgment}

This work was supported in part by University of Sydney Early Career Research Grant awarded to Yuen Ting Lam.

\section{References}

[1] D. Harman, "Aging: a theory based on free radical and radiation chemistry," Journal of Gerontology, vol. 11, no. 3, pp. 298-300, 1956.

[2] A. Bokov, A. Chaudhuri, and A. Richardson, "The role of oxidative damage and stress in aging," Mechanisms of Ageing and Development, vol. 125, no. 10-11, pp. 811-826, 2004.

[3] F. L. Muller, M. S. Lustgarten, Y. Jang, A. Richardson, and H. Van Remmen, "Trends in oxidative aging theories," Free Radical Biology and Medicine, vol. 43, no. 4, pp. 477-503, 2007.

[4] H. Klinger, M. Rinnerthaler, Y. T. Lam et al., "Quantitation of (a)symmetric inheritance of functional and of oxidatively damaged mitochondrial aconitase in the cell division of old yeast mother cells," Experimental Gerontology, vol. 45, no. 7-8, pp. 533-542, 2010.

[5] Y. T. Lam, R. Stocker, and I. W. Dawes, “The lipophilic antioxidants $\alpha$-tocopherol and coenzyme $\mathrm{Q}_{10}$ reduce the replicative lifespan of Saccharomyces cerevisiae," Free Radical Biology and Medicine, vol. 49, no. 2, pp. 237-244, 2010.

[6] Y. T. Lam, M. T. Aung-Htut, Y. L. Lim, H. Yang, and I. W. Dawes, "Changes in reactive oxygen species begin early during replicative aging of Saccharomyces cerevisiae cells," Free Radical Biology and Medicine, vol. 50, no. 8, pp. 963-970, 2011. 
[7] D. B. Lombard, K. F. Chua, R. Mostoslavsky, S. Franco, M. Gostissa, and F. W. Alt, "DNA repair, genome stability, and aging," Cell, vol. 120, no. 4, pp. 497-512, 2005.

[8] C. Piccoli, F. Agriesti, R. Scrima, F. Falzetti, M. Di Ianni, and N. Capitanio, "To breathe or not to breathe: the haematopoietic stem/progenitor cells dilemma," British Journal of Pharmacology, vol. 169, no. 8, pp. 1652-1671, 2013.

[9] E. G. Lakatta and D. Levy, "Arterial and cardiac aging: Major shareholders in cardiovascular disease enterprises: part I: aging arteries: A 'set up' for vascular disease," Circulation, vol. 107, no. 1, pp. 139-146, 2003.

[10] A. Rivard, J.-E. Fabre, M. Silver et al., "Age-dependent impairment of angiogenesis," Circulation, vol. 99, no. 1, pp. 111-120, 1999.

[11] E. I. Chang, S. A. Loh, D. J. Ceradini et al., "Age decreases endothelial progenitor cell recruitment through decreases in hypoxia-inducible factor 1 alpha stabilization during ischemia," Circulation, vol. 116, no. 24, pp. 2818-2829, 2007.

[12] X. Zhang, K. Sarkar, S. Rey et al., "Aging impairs the mobilization and homing of bone marrow-derived angiogenic cells to burn wounds," Journal of Molecular Medicine, vol. 89, no. 10, pp. 985-995, 2011.

[13] F. Timmermans, F. Van Hauwermeiren, M. De Smedt et al., "Endothelial outgrowth cells are not derived from $\mathrm{CD}_{133^{+}}$cells or CD $45^{+}$hematopoietic precursors," Arteriosclerosis, Thrombosis, and Vascular Biology, vol. 27, no. 7, pp. 1572-1579, 2007.

[14] M. C. Yoder, L. E. Mead, D. Prater et al., "Redefining endothelial progenitor cells via clonal analysis and hematopoietic stem/progenitor cell principals," Blood, vol. 109, no. 5, pp. 18011809, 2007.

[15] M. Prokopi, G. Pula, U. Mayr et al., "Proteomic analysis reveals presence of platelet microparticles in endothelial progenitor cell cultures," Blood, vol. 114, no. 3, pp. 723-732, 2009.

[16] F. M. Rauscher, P. J. Goldschmidt-Clermont, B. H. Davis et al., "Aging, progenitor cell exhaustion, and atherosclerosis," Circulation, vol. 108, no. 4, pp. 457-463, 2003.

[17] W. Zhang, G. Zhang, H. Jin, and R. Hu, "Characteristics of bone marrow-derived endothelial progenitor cells in aged mice," Biochemical and Biophysical Research Communications, vol. 348, no. 3, pp. 1018-1023, 2006.

[18] S. Sugihara, Y. Yamamoto, T. Matsuura et al., "Age-related BMMNC dysfunction hampers neovascularization," Mechanisms of Ageing and Development, vol. 128, no. 9, pp. 511-516, 2007.

[19] T. Shimada, Y. Takeshita, T. Murohara et al., "Angiogenesis and vasculogenesis are impaired in the precocious-aging klotho mouse," Circulation, vol. 110, no. 9, pp. 1148-1155, 2004.

[20] Y. Zhuo, S.-H. Li, M.-S. Chen et al., "Aging impairs the angiogenic response to ischemic injury and the activity of implanted cells: combined consequences for cell therapy in older recipients," Journal of Thoracic and Cardiovascular Surgery, vol. 139, no. 5, pp. 1286.e2-1294.e2, 2010.

[21] H. Shao, Q. Xu, Q. Wu et al., "Defective CXCR4 expression in aged bone marrow cells impairs vascular regeneration," Journal of Cellular and Molecular Medicine, vol. 15, no. 10, pp. 20462056, 2011.

[22] R. A. Boon, C. Urbich, A. Fischer et al., "Krüppel-like factor 2 improves neovascularization capacity of aged proangiogenic cells," European Heart Journal, vol. 32, no. 3, pp. 371-377, 2011.

[23] R. J. Scheubel, H. Zorn, R.-E. Silber et al., "Age-dependent depression in circulating endothelial progenitor cells inpatients undergoing coronary artery bypass grafting," Journal of the
American College of Cardiology, vol. 42, no. 12, pp. 2073-2080, 2003.

[24] C. Heiss, S. Keymel, U. Niesler, J. Ziemann, M. Kelm, and C. Kalka, "Impaired progenitor cell activity in age-related endothelial dysfunction," Journal of the American College of Cardiology, vol. 45, no. 9, pp. 1441-1448, 2005.

[25] A. Kawamoto, H.-C. Gwon, H. Iwaguro et al., "Therapeutic potential of ex vivo expanded endothelial progenitor cells for myocardial ischemia," Circulation, vol. 103, no. 5, pp. 634-637, 2001.

[26] C. Urbich, C. Heeschen, A. Aicher, E. Dernbach, A. M. Zeiher, and S. Dimmeler, "Relevance of monocytic features for neovascularization capacity of circulating endothelial progenitor cells," Circulation, vol. 108, no. 20, pp. 2511-2516, 2003.

[27] G. C. Schatteman, H. D. Hanlon, C. Jiao, S. G. Dodds, and B. A. Christy, "Blood-derived angioblasts accelerate bloodflow restoration in diabetic mice," The Journal of Clinical Investigation, vol. 106, no. 4, pp. 571-578, 2000.

[28] A. Taguchi, T. Soma, H. Tanaka et al., "Administration of CD $34^{+}$ cells after stroke enhances neurogenesis via angiogenesis in a mouse model," Journal of Clinical Investigation, vol. 114, no. 3, pp. 330-338, 2004.

[29] H. Iwaguro, J.-I. Yamaguchi, C. Kalka et al., "Endothelial progenitor cell vascular endothelial growth factor gene transfer for vascular regeneration," Circulation, vol. 105, no. 6, pp. 732$738,2002$.

[30] M. Takahashi, T. Nakamura, T. Toba, N. Kajiwara, H. Kato, and Y. Shimizu, "Transplantation of endothelial progenitor cells into the lung to alleviate pulmonary hypertension in dogs," Tissue Engineering, vol. 10, no. 5-6, pp. 771-779, 2004.

[31] T. He, L. A. Smith, S. Harrington, K. A. Nath, N. M. Caplice, and Z. S. Katusic, "Transplantation of circulating endothelial progenitor cells restores endothelial function of denuded rabbit carotid arteries," Stroke, vol. 35, no. 10, pp. 2378-2384, 2004.

[32] T. Yoshioka, N. Ageyama, H. Shibata et al., "Repair of infarcted myocardium mediated by transplanted bone marrow-derived CD $34^{+}$stem cells in a nonhuman primate model," Stem Cells, vol. 23, no. 3, pp. 355-364, 2005.

[33] G. P. Meyer, K. C. Wollert, J. Lotz et al., "Intracoronary bone marrow cell transfer after myocardial infarction: 5-year followup from the randomized-controlled BOOST trial," European Heart Journal, vol. 30, no. 24, pp. 2978-2984, 2009.

[34] V. Schächinger, S. Erbs, A. Elsässer et al., "Improved clinical outcome after intracoronary administration of bone-marrowderived progenitor cells in acute myocardial infarction: final 1year results of the REPAIR-AMI trial," European Heart Journal, vol. 27, no. 23, pp. 2775-2783, 2006.

[35] V. Schächinger, T. Tonn, S. Dimmeler, and A. M. Zeiher, "Bonemarrow-derived progenitor cell therapy in need of proof of concept: design of the REPAIR-AMI trial," Nature Clinical Practice Cardiovascular Medicine, vol. 3, supplement 1, pp. S23S28, 2006.

[36] V. Schächinger, B. Assmus, S. Erbs et al., "Intracoronary infusion of bone marrow-derived mononuclear cells abrogates adverse left ventricular remodelling post-acute myocardial infarction: insights from the reinfusion of enriched progenitor cells and infarct remodelling in acute myocardial infarction (REPAIR-AMI) trial," European Journal of Heart Failure, vol. 11, no. 10, pp. 973-979, 2009.

[37] S. Janssens, C. Dubois, J. Bogaert et al., "Autologous bone marrow-derived stem-cell transfer in patients with ST-segment 
elevation myocardial infarction: double-blind, randomised controlled trial," The Lancet, vol. 367, no. 9505, pp. 113-121, 2006.

[38] K. Lunde, S. Solheim, S. Aakhus et al., "Intracoronary injection of mononuclear bone marrow cells in acute myocardial infarction," The New England Journal of Medicine, vol. 355, no. 12, pp. 1199-1209, 2006.

[39] M. Yousef, C. M. Schannwell, M. Köstering, T. Zeus, M. Brehm, and B. E. Strauer, "The BALANCE study: clinical benefit and long-term outcome after intracoronary autologous bone marrow cell transplantation in patients with acute myocardial infarction," Journal of the American College of Cardiology, vol. 53, no. 24, pp. 2262-2269, 2009.

[40] J. Bartunek, M. Vanderheyden, B. Vandekerckhove et al., "Intracoronary injection of CD133-positive enriched bone marrow progenitor cells promotes cardiac recovery after recent myocardial infarction: feasibility and safety," Circulation, vol. 112, no. 9, supplement, pp. I178-I183, 2005.

[41] M. Vanderheyden, S. Vercauteren, S. Mansour et al., "Timedependent effects on coronary remodeling and epicardial conductance after intracoronary injection of enriched hematopoietic bone marrow stem cells in patients with previous myocardial infarction," Cell Transplantation, vol. 16, no. 9, pp. 919-925, 2007.

[42] H. Ahmadi, H. Baharvand, S. K. Ashtiani et al., "Safety analysis and improved cardiac function following local autologous transplantation of $\mathrm{CD}_{133^{+}}$enriched bone marrow cells after myocardial infarction," Current Neurovascular Research, vol. 4, no. 3, pp. 153-160, 2007.

[43] M. Tendera, W. Wojakowski, W. Ruyłło et al., "Intracoronary infusion of bone marrow-derived selected $\mathrm{CD} 34^{+} \mathrm{CXCR} 4^{+}$cells and non-selected mononuclear cells in patients with acute STEMI and reduced left ventricular ejection fraction: results of randomized, multicentre Myocardial Regeneration by Intracoronary Infusion of Selected Population of Stem Cells in Acute Myocardial Infarction (REGENT) Trial," European Heart Journal, vol. 30, no. 11, pp. 1313-1321, 2009.

[44] J. M. Hare, J. H. Traverse, T. D. Henry et al., "A randomized, double-blind, placebo-controlled, dose-escalation study of intravenous adult human mesenchymal stem cells (prochymal) after acute myocardial infarction," Journal of the American College of Cardiology, vol. 54, no. 24, pp. 2277-2286, 2009.

[45] U. M. Fischer, M. T. Harting, F. Jimenez et al., "Pulmonary passage is a major obstacle for intravenous stem cell delivery: the pulmonary first-pass effect," Stem Cells and Development, vol. 18, no. 5, pp. 683-691, 2009.

[46] B. Assmus, J. Honold, V. Schächinger et al., "Transcoronary transplantation of progenitor cells after myocardial infarction," The New England Journal of Medicine, vol. 355, no. 12, pp. 12221232, 2006.

[47] B. Assmus, A. Rolf, S. Erbs et al., "Clinical outcome 2 years after intracoronary administration of bone marrow-derived progenitor cells in acute myocardial infarction," Circulation: Heart Failure, vol. 3, no. 1, pp. 89-96, 2010.

[48] P. Menasché, O. Alfieri, S. Janssens et al., "The myoblast autologous grafting in ischemic cardiomyopathy (MAGIC) trial: first randomized placebo-controlled study of myoblast transplantation," Circulation, vol. 117, no. 9, pp. 1189-1200, 2008.

[49] B.-E. Strauer, M. Yousef, and C. M. Schannwell, “The acute and long-term effects of intracoronary Stem cell Transplantation in 191 patients with chronic heARt failure: the STAR-heart study," European Journal of Heart Failure, vol. 12, no. 7, pp. 721-729, 2010.
[50] J. van Ramshorst, J. J. Bax, S. L. M. A. Beeres et al., "Intramyocardial bone marrow cell injection for chronic myocardial ischemia: a randomized controlled trial," The Journal of the American Medical Association, vol. 301, no. 19, pp. 1997-2004, 2009.

[51] D. W. Losordo, R. A. Schatz, C. J. White et al., "Intramyocardial transplantation of autologous $\mathrm{CD} 34^{+}$stem cells for intractable angina: a phase I/IIa double-blind, randomized controlled trial," Circulation, vol. 115, no. 25, pp. 3165-3172, 2007.

[52] D. W. Losordo, T. D. Henry, C. Davidson et al., "Intramyocardial, autologous CD34+ cell therapy for refractory angina," Circulation Research, vol. 109, no. 4, pp. 428-436, 2011.

[53] H.-F. Tse, S. Thambar, Y.-L. Kwong et al., "Prospective randomized trial of direct endomyocardial implantation of bone marrow cells for treatment of severe coronary artery diseases (PROTECT-CAD trial)," European Heart Journal, vol. 28, no. 24, pp. 2998-3005, 2007.

[54] S. J. Morrison and A. C. Spradling, "Stem cells and niches: mechanisms that promote stem cell maintenance throughout life," Cell, vol. 132, no. 4, pp. 598-611, 2008.

[55] K. Parmar, P. Mauch, J.-A. Vergilio, R. Sackstein, and J. D. Down, "Distribution of hematopoietic stem cells in the bone marrow according to regional hypoxia," Proceedings of the National Academy of Sciences of the United States of America, vol. 104, no. 13, pp. 5431-5436, 2007.

[56] T. Suda, K. Takubo, and G. L. Semenza, "Metabolic regulation of hematopoietic stem cells in the hypoxic niche," Cell Stem Cell, vol. 9, no. 4, pp. 298-310, 2011.

[57] Y.-Y. Jang and S. J. Sharkis, "A low level of reactive oxygen species selects for primitive hematopoietic stem cells that may reside in the low-oxygenic niche," Blood, vol. 110, no. 8, pp. 3056-3063, 2007.

[58] S. J. Morrison, K. R. Prowse, P. Ho, and I. L. Weissman, "Telomerase activity in hematopoietic cells is associated with self-renewal potential," Immunity, vol. 5, no. 3, pp. 207-216, 1996.

[59] J. Krishnamurthy, C. Torrice, M. R. Ramsey et al., "Ink4a/Arf expression is a biomarker of aging," The Journal of Clinical Investigation, vol. 114, no. 9, pp. 1299-1307, 2004.

[60] V. Janzen, R. Forkert, H. E. Fleming et al., "Stem-cell ageing modified by the cyclin-dependent kinase inhibitor p16 INK4a," Nature, vol. 443, no. 7110, pp. 421-426, 2006.

[61] K. Ito, A. Hirao, F. Arai et al., "Reactive oxygen species act through p38 MAPK to limit the lifespan of hematopoietic stem cells," Nature Medicine, vol. 12, no. 4, pp. 446-451, 2006.

[62] G. Saretzki, L. Armstrong, A. Leake, M. Lako, and T. Von Zglinicki, "Stress defense in murine embryonic stem cells is superior to that of various differentiated murine cells," Stem Cells, vol. 22, no. 6, pp. 962-971, 2004.

[63] M. Buggisch, B. Ateghang, C. Ruhe et al., "Stimulation of ES-cell-derived cardiomyogenesis and neonatal cardiac cell proliferation by reactive oxygen species and NADPH oxidase," Journal of Cell Science, vol. 120, no. 5, pp. 885-894, 2007.

[64] L. Zuo and T. L. Clanton, "Reactive oxygen species formation in the transition to hypoxia in skeletal muscle," American Journal of Physiology-Cell Physiology, vol. 289, no. 1, pp. C207-C216, 2005.

[65] D. R. S. Steiner, N. C. Gonzalez, and J. G. Wood, "Interaction between reactive oxygen species and nitric oxide in the microvascular response to systemic hypoxia," Journal of Applied Physiology, vol. 93, no. 4, pp. 1411-1418, 2002. 
[66] J. D. Stoner, T. L. Clanton, S. E. Aune, and M. G. Angelos, " $\mathrm{O}_{2}$ delivery and redox state are determinants of compartmentspecific reactive $\mathrm{O}_{2}$ species in myocardial reperfusion," The American Journal of Physiology - Heart and Circulatory Physiology, vol. 292, no. 1, pp. H109-H116, 2007.

[67] N. Urao, R. D. McKinney, T. Fukai, and M. Ushio-Fukai, "NADPH oxidase 2 regulates bone marrow microenvironment following hindlimb ischemia: role in reparative mobilization of progenitor cells," Stem Cells, vol. 30, no. 5, pp. 923-934, 2012.

[68] J.-P. Lévesque, I. G. Winkler, J. Hendy et al., "Hematopoietic progenitor cell mobilization results in hypoxia with increased hypoxia-inducible transcription factor-1 alpha and vascular endothelial growth factor A in bone marrow," Stem Cells, vol. 25, no. 8, pp. 1954-1965, 2007.

[69] N. Urao, H. Inomata, M. Razvi et al., "Role of nox2-based NADPH oxidase in bone marrow and progenitor cell function involved in neovascularization induced by hindlimb ischemia," Circulation Research, vol. 103, no. 2, pp. 212-220, 2008.

[70] J. Fan, H. Cai, and W.-S. Tan, "Role of the plasma membrane ROS-generating NADPH oxidase in $\mathrm{CD} 34^{+}$progenitor cells preservation by hypoxia," Journal of Biotechnology, vol. 130, no. 4, pp. 455-462, 2007.

[71] C. Piccoli, A. D’Aprile, M. Ripoli et al., "Bone-marrow derived hematopoietic stem/progenitor cells express multiple isoforms of NADPH oxidase and produce constitutively reactive oxygen species," Biochemical and Biophysical Research Communications, vol. 353, no. 4, pp. 965-972, 2007.

[72] N. Wang, K. Xie, S. Huo, J. Zhao, S. Zhang, and J. Miao, "Suppressing phosphatidylcholine-specific phospholipase $\mathrm{C}$ and elevating ROS level, NADPH oxidase activity and Rb level induced neuronal differentiation in mesenchymal stem cells," Journal of Cellular Biochemistry, vol. 100, no. 6, pp. 1548-1557, 2007.

[73] C. Piccoli, A. D’Aprile, M. Ripoli et al., "The hypoxia-inducible factor is stabilized in circulating hematopoietic stem cells under normoxic conditions," FEBS Letters, vol. 581, no. 16, pp. 31113119, 2007.

[74] T. Yahata, T. Takanashi, Y. Muguruma et al., "Accumulation of oxidative DNA damage restricts the self-renewal capacity of human hematopoietic stem cells," Blood, vol. 118, no. 11, pp. 2941-2950, 2011.

[75] E. Dernbach, C. Urbich, R. P. Brandes, W. K. Hofmann, A. M. Zeiher, and S. Dimmeler, "Antioxidative stress-associated genes in circulating progenitor cells: evidence for enhanced resistance against oxidative stress," Blood, vol. 104, no. 12, pp. 3591-3597, 2004.

[76] T. He, T. E. Peterson, E. L. Holmuhamedov et al., "Human endothelial progenitor cells tolerate oxidative stress due to intrinsically high expression of manganese superoxide dismutase," Arteriosclerosis, Thrombosis, and Vascular Biology, vol. 24, no. 11, pp. 2021-2027, 2004.

[77] T. Asahara, T. Murohara, A. Sullivan et al., "Isolation of putative progenitor endothelial cells for angiogenesis," Science, vol. 275, no. 5302, pp. 964-967, 1997.

[78] D. P. Sieveking, A. Buckle, D. S. Celermajer, and M. K. C. $\mathrm{Ng}$, "Strikingly different angiogenic properties of endothelial progenitor cell subpopulations: insights from a novel human angiogenesis assay," Journal of the American College of Cardiology, vol. 51, no. 6, pp. 660-668, 2008.

[79] M. Iiyama, K. Kakihana, T. Kurosu, and O. Miura, "Reactive oxygen species generated by hematopoietic cytokines play roles in activation of receptor-mediated signaling and in cell cycle progression," Cellular Signalling, vol. 18, no. 2, pp. 174-182, 2006.
[80] D. J. Ceradini, A. R. Kulkarni, M. J. Callaghan et al., "Progenitor cell trafficking is regulated by hypoxic gradients through HIF-1 induction of SDF-1," Nature Medicine, vol. 10, no. 8, pp. 858-864, 2004.

[81] M. Tesio, K. Golan, S. Corso et al., "Enhanced c-met activity promotes G-CSF-induced mobilization of hematopoietic progenitor cells via ROS signaling," Blood, vol. 117, no. 2, pp. 419428, 2011.

[82] L. Trusolino and P. M. Comoglio, "Scatter-factor and semaphorin receptors: cell signalling for invasive growth," Nature Reviews Cancer, vol. 2, no. 4, pp. 289-300, 2002.

[83] S. Rafii, S. Avecilla, S. Shmelkov et al., "Angiogenic factors reconstitute hematopoiesis by recruiting stem cells from bone marrow microenvironment," Annals of the New York Academy of Sciences, vol. 996, pp. 49-60, 2003.

[84] N. Maulik, "Redox signaling of angiogenesis," Antioxidants and Redox Signaling, vol. 4, no. 5, pp. 805-815, 2002.

[85] M. Ushio-Fukai, Y. Tang, T. Fukai et al., "Novel role of gp91(phox)-containing NAD(P)H oxidase in vascular endothelial growth factor-induced signaling and angiogenesis," Circulation Research, vol. 91, no. 12, pp. 1160-1167, 2002.

[86] T. Tojo, M. Ushio-Fukai, M. Yamaoka-Tojo, S. Ikeda, N. Patrushev, and R. W. Alexander, "Role of gp91" phox (Nox2)-containing $\mathrm{NAD}(\mathrm{P}) \mathrm{H}$ oxidase in angiogenesis in response to hindlimb ischemia," Circulation, vol. 111, no. 18, pp. 2347-2355, 2005.

[87] J. Chen, C. M. Astle, and D. E. Harrison, "Genetic regulation of primitive hematopoietic stem cell senescence," Experimental Hematology, vol. 28, no. 4, pp. 442-450, 2000.

[88] P. Rimmelé, C. L. Bigarella, R. Liang et al., "Aging-like phenotype and defective lineage specification in SIRT1-deleted hematopoietic stem and progenitor cells," Stem Cell Reports, vol. 3, no. 1, pp. 44-59, 2014.

[89] H.-F. Yuan, C. Zhai, X.-L. Yan et al., "SIRT1 is required for long-term growth of human mesenchymal stem cells," Journal of Molecular Medicine, vol. 90, no. 4, pp. 389-400, 2012.

[90] K. Brown, S. Xie, X. Qiu et al., "SIRT3 reverses aging-associated degeneration," Cell Reports, vol. 3, no. 2, pp. 319-327, 2013.

[91] R. Tao, M. C. Coleman, J. D. Pennington et al., "Sirt3-mediated deacetylation of evolutionarily conserved lysine 122 regulates MnSOD activity in response to stress," Molecular Cell, vol. 40, no. 6, pp. 893-904, 2010.

[92] H. Zeng, L. Li, and J.-X. Chen, "Loss of Sirt3 limits bone marrow cell-mediated angiogenesis and cardiac repair in postmyocardial infarction," PLoS ONE, vol. 9, no. 9, Article ID e107011, 2014.

[93] A. R. Brasier, A. Recinos III, M. S. Eledrisi, and M. S. Runge, "Vascular inflammation and the renin-angiotensin system," Arteriosclerosis, Thrombosis, and Vascular Biology, vol. 22, no. 8, pp. 1257-1266, 2002.

[94] Z. J. Cheng, H. Vapaatalo, and E. Mervaala, "Angiotensin II and vascular inflammation," Medical Science Monitor, vol. 11, no. 6, pp. RA194-RA205, 2005.

[95] A. A. Domenighetti, Q. Wang, M. Egger, S. M. Richards, T. Pedrazzini, and L. M. D. Delbridge, "Angiotensin II-mediated phenotypic cardiomyocyte remodeling leads to age-dependent cardiac dysfunction and failure," Hypertension, vol. 46, no. 2, pp. 426-432, 2005.

[96] T. Q. Min, C. J. Zhu, W. X. Xiang, Z. J. Hui, and S. Y. Peng, "Improvement in endothelial progenitor cells from peripheral blood by ramipril therapy in patients with stable coronary artery disease," Cardiovascular Drugs and Therapy, vol. 18, no. 3, pp. 203-209, 2004. 
[97] T. Imanishi, T. Hano, and I. Nishio, "Angiotensin II accelerates endothelial progenitor cell senescence through induction of oxidative stress," Journal of Hypertension, vol. 23, no. 1, pp. 97104, 2005.

[98] F. Sanada, Y. Taniyama, J. Azuma et al., "Hepatocyte growth factor, but not vascular endothelial growth factor, attenuates angiotensin II-induced endothelial progenitor cell senescence," Hypertension, vol. 53, no. 1, pp. 77-82, 2009.

[99] K. Ito, A. Hirao, F. Arai et al., "Regulation of oxidative stress by ATM is required for self-renewal of haematopoietic stem cells," Nature, vol. 431, no. 7011, pp. 997-1002, 2004.

[100] K. Miyamoto, K. Y. Araki, K. Naka et al., "Foxo3a is essential for maintenance of the hematopoietic stem cell pool," Cell Stem Cell, vol. 1, no. 1, pp. 101-112, 2007.

[101] Z. Tothova, R. Kollipara, B. J. Huntly et al., "FoxOs are critical mediators of hematopoietic stem cell resistance to physiologic oxidative stress," Cell, vol. 128, no. 2, pp. 325-339, 2007.

[102] G. K. Asimakis, S. Lick, and C. Patterson, "Postischemic recovery of contractile function is impaired in SOD2(+/-) but not SOD1(+/-) mouse hearts," Circulation, vol. 105, no. 8, pp. 981-986, 2002.

[103] S. P. Didion, D. A. Kinzenbaw, L. I. Schrader, and F. M. Faraci, "Heterozygous CuZn superoxide dismutase deficiency produces a vascular phenotype with aging," Hypertension, vol. 48, no. 6, pp. 1072-1079, 2006.

[104] J. Groleau, S. Dussault, J. Turgeon, P. Haddad, and A. Rivard, "Accelerated vascular aging in CuZnSOD-deficient mice: impact on EPC function and reparative neovascularization," PLoS ONE, vol. 6, no. 8, Article ID e23308, 2011.

[105] J. Groleau, S. Dussault, P. Haddad et al., "Essential role of copper-zinc superoxide dismutase for ischemia-induced neovascularization via modulation of bone marrow-derived endothelial progenitor cells," Arteriosclerosis, Thrombosis, and Vascular Biology, vol. 30, no. 11, pp. 2173-2181, 2010.

[106] E. Čolak, N. Majkić-Singh, S. Stanković et al., "Parameters of antioxidative defense in type 2 diabetic patients with cardiovascular complications," Annals of Medicine, vol. 37, no. 8, pp. 613620, 2005.

[107] A. Linke, V. Adams, P. C. Schulze et al., "Antioxidative effects of exercise training in patients with chronic heart failure: increase in radical scavenger enzyme activity in skeletal muscle," Circulation, vol. 111, no. 14, pp. 1763-1770, 2005.

[108] M. Vasa, S. Fichtlscherer, A. Aicher et al., "Number and migratory activity of circulating endothelial progenitor cells inversely correlate with risk factors for coronary artery disease," Circulation Research, vol. 89, no. 1, pp. e1-e7, 2001.

[109] J. Turgeon, P. Haddad, S. Dussault et al., "Protection against vascular aging in Nox2-deficient mice: impact on endothelial progenitor cells and reparative neovascularization," Atherosclerosis, vol. 223, no. 1, pp. 122-129, 2012.

[110] D. J. Ceradini, D. Yao, R. H. Grogan et al., "Decreasing intracellular superoxide corrects defective ischemia-induced new vessel formation in diabetic mice," The Journal of Biological Chemistry, vol. 283, no. 16, pp. 10930-10938, 2008.

[111] M. Ohshima, T.-S. Li, M. Kubo, S.-L. Qin, and K. Hamano, "Antioxidant therapy attenuates diabetes-related impairment of bone marrow stem cells," Circulation Journal, vol. 73, no. 1, pp. 162-166, 2009.

[112] H. Song, M.-J. Cha, B.-W. Song et al., "Reactive oxygen species inhibit adhesion of mesenchymal stem cells implanted into ischemic myocardium via interference of focal adhesion complex," Stem Cells, vol. 28, no. 3, pp. 555-563, 2010.
[113] N. I. Moldovan, M. Anghelina, S. Varadharaj et al., "Reoxygenation-derived toxic reactive oxygen/nitrogen species modulate the contribution of bone marrow progenitor cells to remodeling after myocardial infarction," Journal of the American Heart Association, vol. 3, no. 1, Article ID e000471, 2014.

[114] H. W. Kim, H. K. Haider, S. Jiang, and M. Ashraf, "Ischemic preconditioning augments survival of stem cells via miR-210 expression by targeting caspase-8-associated protein 2," Journal of Biological Chemistry, vol. 284, no. 48, pp. 33161-33168, 2009.

[115] S. W. Kim, H. W. Kim, W. Huang et al., "Cardiac stem cells with electrical stimulation improve ischaemic heart function through regulation of connective tissue growth factor and miR378," Cardiovascular Research, vol. 100, no. 2, pp. 241-251, 2013.

[116] M. Kubo, T.-S. Li, R. Suzuki, M. Ohshima, S.-L. Qin, and K. Hamano, "Short-term pretreatment with low-dose hydrogen peroxide enhances the efficacy of bone marrow cells for therapeutic angiogenesis," The American Journal of PhysiologyHeart and Circulatory Physiology, vol. 292, no. 6, pp. H2582H2588, 2007.

[117] A. Carrière, T. G. Ebrahimian, S. Dehez et al., "Preconditioning by mitochondrial reactive oxygen species improves the proangiogenic potential of adipose-derived cells-based therapy," Arteriosclerosis, Thrombosis, and Vascular Biology, vol. 29, no. 7, pp. 1093-1099, 2009.

[118] M. Kubo, T.-S. Li, H. Kurazumi et al., "Hypoxic preconditioning enhances angiogenic potential of bone marrow cells with agingrelated functional impairment," Circulation Journal, vol. 76, no. 4, pp. 986-994, 2012.

[119] S. D. Barros, S. Dehez, E. Arnaud et al., "Aging-related decrease of human ASC angiogenic potential is reversed by hypoxia preconditioning through ROS production," Molecular Therapy, vol. 21, no. 2, pp. 399-408, 2013.

[120] S. Rey, W. Luo, L. A. Shimoda, and G. L. Semenza, "Metabolic reprogramming by HIF-1 promotes the survival of bone marrow-derived angiogenic cells in ischemic tissue," Blood, vol. 117, no. 18, pp. 4988-4998, 2011. 


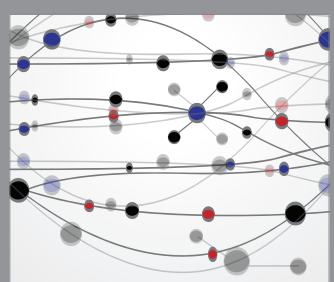

The Scientific World Journal
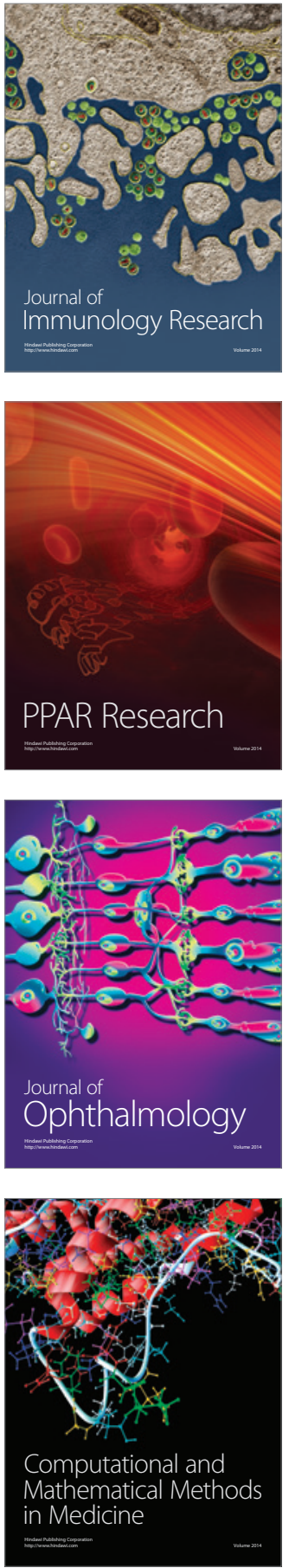

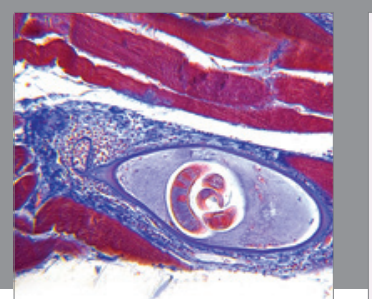

Gastroenterology Research and Practice

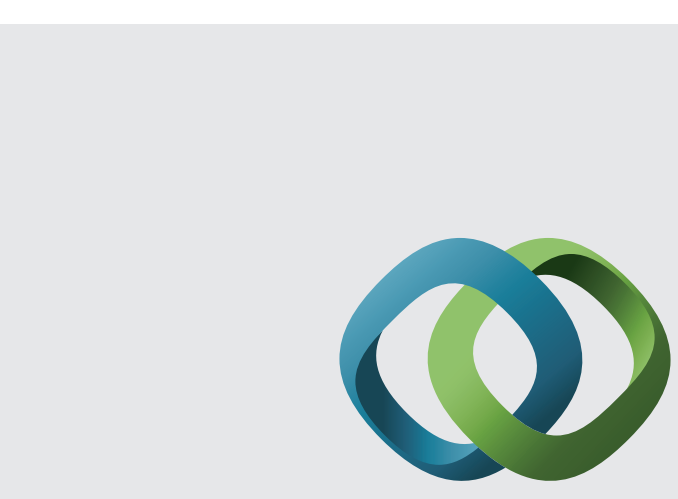

\section{Hindawi}

Submit your manuscripts at

http://www.hindawi.com
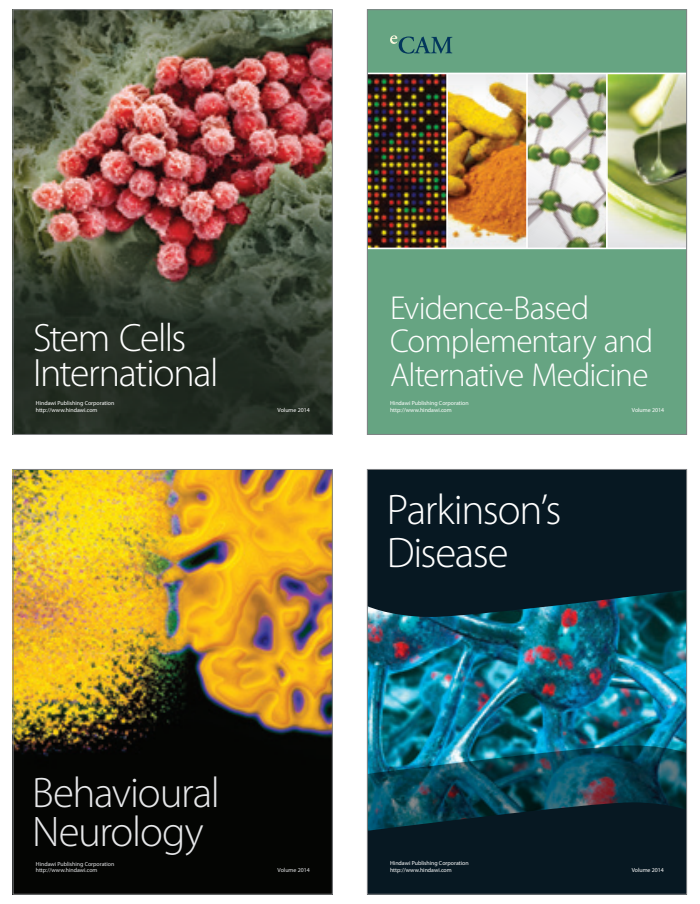
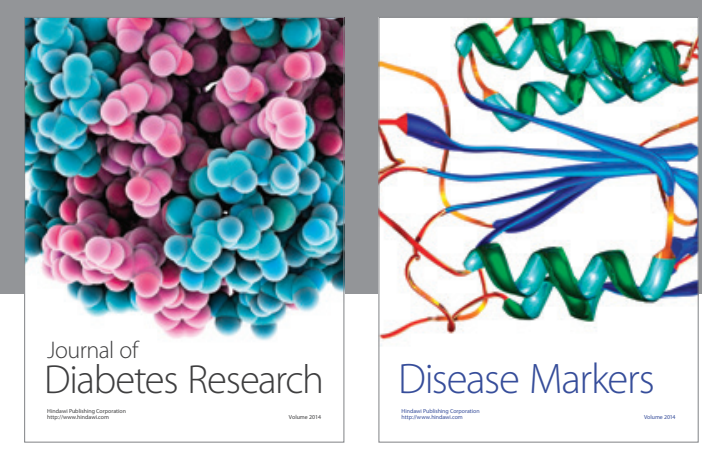

Disease Markers
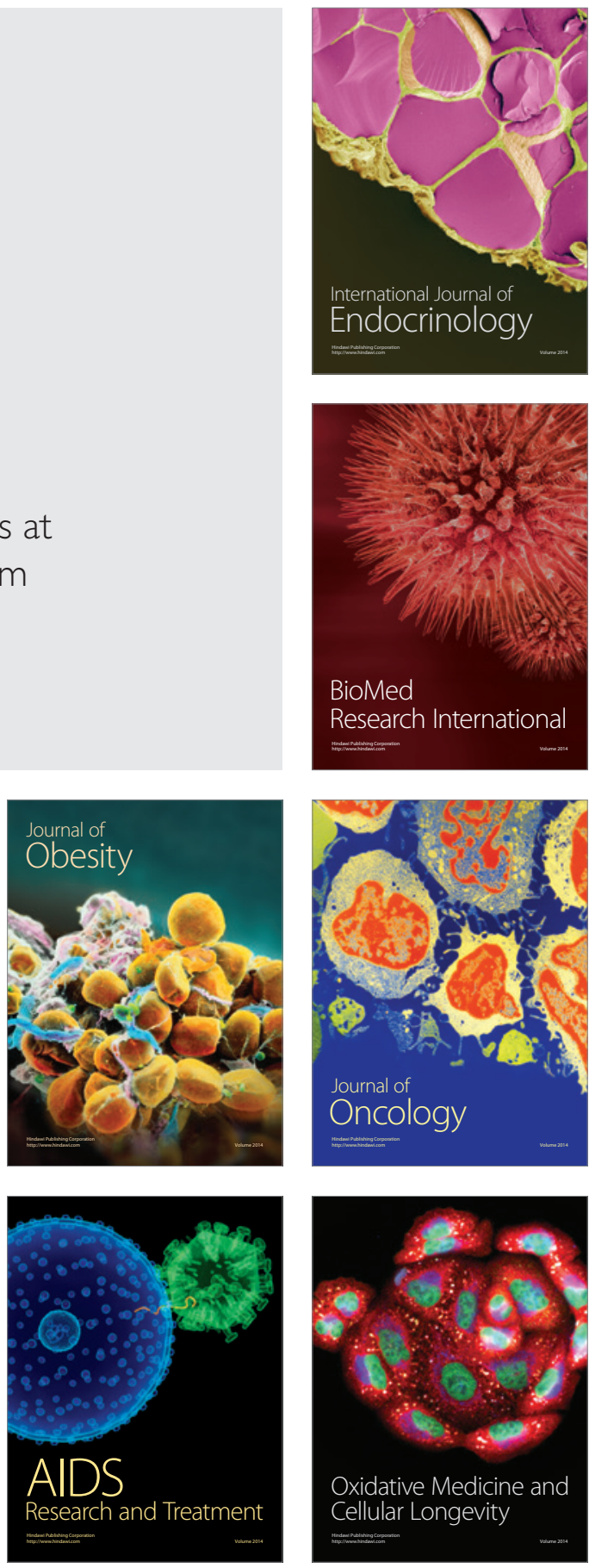